\title{
Between Consumer Demand and Islamic Law: The Evolution of Islamic Credit Cards in Turkey
}

\author{
Murat Timur Kuran \\ Çokgezen \\ Marmara University \\ Duke University \\ July 27,2015 \\ ERID Working Paper Number 182
}

This paper can be downloaded without charge from the Social

Science Research Network Electronic Paper Collection:

http://ssrn.com/abstract=2553445

Economic Research Initiatives at Duke WORKING PAPERS SERIES

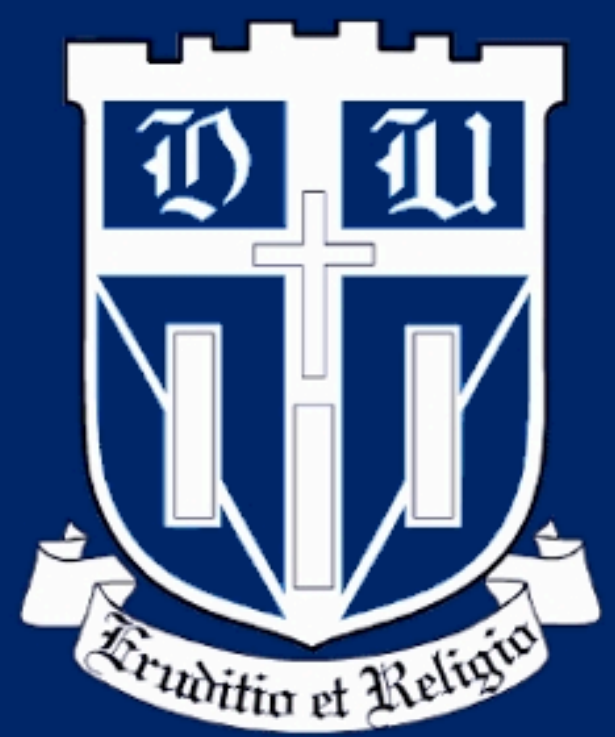




\title{
Between Consumer Demand and Islamic Law: The Evolution of Islamic Credit Cards in Turkey
}

\author{
Murat Çokgezen ${ }^{\mathrm{a}}$, Timur Kuran ${ }^{\mathrm{b}, *}$ \\ ${ }^{\text {a }}$ Marmara University, Turkey \\ ${ }^{\mathrm{b}}$ Duke University, USA
}

\begin{abstract}
The elimination of interest from financial transactions has been a salient goal of Islamization movements around the world. Its proponents have had to balance this objective, which they claim to draw from Islamic law (Sharia), against consumer demand for convenient products. In general they have opted to accommodate consumer demand, but surreptitiously, using legal ruses to disguise their compromises. Turkey's experience with credit cards offers a revealing case of the obfuscation in question. Having denounced credit cards as un-Islamic, Turkey's Islamic banks have all proceeded to issue credit cards of their own in order to remain competitive with their openly interest-friendly, conventional rivals. With local variations, the Turkish pattern resembles that of other markets where Islamic credit cards have made inroads. In Malaysia and the United Arab Emirates, too, Islamic credit cards function like those of the conventional banks with which they compete for customers. The "Islamic" features of Islamic credit cards amount to branding. Contrary to the claims of their proponents, they do not involve fundamental financial innovations.
\end{abstract}

Highlights:

Islamic credit cards functionally indistinct

Main variations between countries

Keywords: Banking, Credit card, Islam, Interest, Turkey.

JEL classification: G23, O53, P46, K29

${ }^{\mathrm{c}}$ We are grateful to Pongsakorn Suwanpong and Rong Chen for dedicated research assistance, and to Okan Acar, Abdülaziz Bayındır, Ahmet Çilingirtürk, Aydın Yabanlı, and Ünsal Sözbir for useful discussions. Two anonymous referees provided helpful feedback. The officials of two organizations, the Association of Turkish Participation Banks and the Kuwait Turkish Bank, supplied data and insights. The Earhart Foundation supported Kuran's work.

* Corresponding author.

E-mail addresses: mcokgez@marmara.edu.tr (M. Çokgezen), t.kuran@ duke.edu (T. Kuran)

Corresponding author's physical address and phone numbers: Timur Kuran, Department of Economics, PO Box 90097, Duke University, Durham, NC 27708, USA. [Office phone: 1 (919) 660-1872; Cell phone: 1 (919) 667-5082; Fax: 1 (919) 667-5082] 


\section{The compatibility of credit cards with Islamic finance}

A credit card provides its owner a line of credit from which he can withdraw money as a cash advance or as payment to a merchant. For a cash advance, he begins to incur interest charges immediately. For a good or service bought from a merchant, he can avoid charges if he repays the bank within a specified period after the transaction appears on his monthly bill. If he fails to pay his bill in full within the alloted time, he starts to incur interest charges. The credit card's owner will continue to accrue interest debts until he pays a monthly bill in full, including accumulated interest charges.

One might expect Islamic banks to have ruled out the use of credit cards categorically. After all, their declared purpose is to conduct banking on an interest-free basis. Indeed, most Islamic scholars consider the conventional credit card un-Islamic (haram) even if the cardholder avoids interest charges by paying the full amount of each monthly bill. One reason is that his contract with the card's issuer commits him to paying interest in the event of a missed payment. Another is that he obtains access to cash advances at interest.

Practically all Islamic banks compete with banks that give and take interest openly and unapologetically. These interest-friendly banks, which may be called "conventional banks" as a short-hand, have no qualms about credit cards. As credit cards gained popularity, they simply fulfilled the swelling demand in order to augment their profits. The same profit opportunities have induced Islamic banks to offer an analogous product. They have responded by issuing ostensibly interest-free credit cards characterized as "halal," "Sharia-compliant," or simply "Islamic."

Our objective is to explore this response to the challenge of supplying credit cards compatible with the principles of Islamic banking. Turkey's Islamic banks differentiate their credit cards from those of conventional Turkish banks partly by disguising their interest charges through euphemisms. They also make their clients agree to refrain from using their credit cards for "un-Islamic" transactions, such as the purchase of alcohol or pork. As a matter of practice, however, the users of Islamic credit cards enjoy the same privileges as those of conventional credit cards. Likewise, the fees that they pay match those paid to conventional banks.

As we shall see, there are differences among the credit cards issued by Islamic banks in different countries. By and large, these cross-country differences mirror the corresponding differences across the financial sectors. In each country Islamic banks have adapted to the conditions of the domestic financial sector. Consequently, the Islamic credit cards of any 
given country function more like the conventional credit cards with which they compete locally than the Islamic cards in use elsewhere. Beyond symbolic features, the world's Islamic credit cards share no characteristics that distinguish them from conventional credit cards.

We start with a description of the Islamic banking sector that generated Turkey's first Islamic credit cards. Then the focus will turn to the credit cards themselves.

\section{Turkey's Islamic banking sector}

Turkey's first Islamic banks were established in 1984 and 1985 in accordance with a law passed in 1983. The pioneers were consortia led by Saudi Arabian and Bahraini investors. ${ }^{1}$ Because of qualms grounded in Turkey's secularist principles, neither bank's name or charter referenced Islam. The Faisal Finance House and the Albaraka Finance House vowed to provide an interest-free alternative to conventional banking. In principle, they took deposits on the basis of profit and loss sharing; and, likewise, their depositors participated in an invesment pool whose returns would not necessarily be positive. If the bank's investments resulted in losses, deposits would shrink. Based on the premise that the depositors of finance houses accepted downside risk, their deposits were not insured. The commercial loans of Faisal and Albaraka were based, again in principle, on profit and loss sharing. They were to earn not interest but variable returns based on the profitability of the projects financed.

Several other finance houses were established over the following years, bringing the total to six by 1996. The largest of the six was the İhlas Finance House, whose capital came mostly from Turkish investors. It went bankrupt during Turkey’s 2001 financial crisis (Eken, 2006). In the absence of deposit insurance, tens of thousands of its depositors and investors lost money, prompting massive withdrawals from all of the finance houses. In response to this shock, the law governing their operations was revised in 2005. Now called "participation banks" (katılım bankaları), their deposits would be insured, as with the deposits of conventional banks, up to TL $50,000 .^{2}$ The insurance limit has since been raised to TL 100,000 .

Mergers and acquisitions reduced the number of participation banks to four by 2005. Three of these are primarily foreign-owned: Albaraka Turkey, Kuveyt Türk (Kuwait-

\footnotetext{
${ }^{1}$ BDDK, 2011; Y1lmaz, 2010. For an extensive bibliography on Islamic banking in Turkey, see Solak (2003).

${ }^{2}$ This happened on February 10, 2001, and eleven days later the remaining Islamic banks initiated efforts to establish a deposit insurance system of their own (Ntvmsnbc, 2009; Yeni Şafak, 2001). They were ultimately unsuccessful. Eventually, on November 1, 2005, a legislative change in banking regulations enabled the Islamic banks to join the insurance system long used by conventional banks. As part of this reform, their legal status changed from "private finance houses" to "participation banks."
} 
Turkish), and Türkiye Finans (Turkey Finance). The only primarily Turkish-owned participation bank, Asya, is also the largest in terms of assets and depositors. Cumulatively, the participation banks held 5.54 percent of the Turkish banking sector's assets at the end of 2013, and 6.66 percent of the deposits. They had 966 branches, which represented 8.05 percent of all the bank branches in Turkey (Table 1).

Table 1 here

Like Islamic banks everywhere, Turkey's participation banks exist to do strictly interest-free banking. Officially, that is what differentiates them from their conventional rivals, and that is the reason why their customers choose them. ${ }^{3}$ In fact, they give and take interest routinely. Their depositors receive returns that are nearly identical to the rates paid by conventional banks. There is no statistically significant difference between the returns of the two groups of depositors. In lending, too, the participation banks impose charges that are practically indistinguishable from interest (Kuran, 2004, 43-46; Çevik and Charap, 2015). ${ }^{4}$ Various studies indicate that the interest rates of Islamic banks track those of conventional banks (Çevik and Charap, 2015; Chong and Liu, 2009).

Each Islamic bank has a Sharia board composed of reputable religious scholars (Table 2). The board rules on what practices conform to Islam. Thus, when a bank wants to release a new product, the plan comes before the board for approval. Evaluating the plan from an Islamic perspective, the board rules on its permissibility. Frequently the board faces a tradeoff between the bank's profitability and abiding by Islamic principles. Because its deliberations and decisions are kept secret, we do not know whether it constrains the bank's operations in any meaningful sense. Some insiders believe that it exists to legitimize whatever the management already favors. ${ }^{5}$

Table 2 here

\footnotetext{
${ }^{3}$ Surveys of the customers of participation banks indicate that religious considerations influence their banking choices (Özsoy, Görmez, and Mekik, 2013; Savaşan, Saraç, and Gürdal, 2013; Karamustafa and Karakaya, 2002).

${ }^{4}$ The high correleation between the interest rates of conventional banks and the profit rates of Islamic banks has subjected executives of Islamic banks to steady questions as to whether their financial practices differ at all from those of the conventional banks that they criticize. In response, they have all issued brochures aimed at comforting their clients. See, for instance, Albaraka Türk (2006), 11; TKBB (undated), 6-7.

${ }^{5}$ Abdülaziz Bayındır, a prestigious scholar and former board member, believes that the boards lack independence. There have been unsuccessful efforts to form an independent body to monitor the practices of Turkey's Islamic banks (TKBB, 2014). Similar attempts have been made outside of Turkey, to control the practices of other Islamic banks (Al Arabiya News, 2012).
} 
The practices of the Islamic banks lend support to the concern that their boards lack independence. As shown in Table 2, several Sharia scholars serve on multiple boards. Two of them, Hayrettin Karaman (b. 1934) and Hamdi Döndüren (b. 1943) serve on the boards of Asya, Türkiye Finans, and Albaraka. A third scholar, İshak Emin Aktepe (b. 1975), serves on two of the four boards. Because board decisions are based on consensus, ${ }^{6}$ the overlap in membership may lead one to expect that boards reach identical judgments with regard to controversial matters. In fact, it is not uncommon for the four bank boards to subscribe to four different interpretations concerning the same product characteristic. In effect, one board treats as sinful what others rule permissible. A report of the Association of Turkish Participation Banks (TKBB, 2014) laments that the resulting variations in Islamic banking practices weaken consumer confidence in the Islamic legitimacy of Islamic banking. The Association proposes to establish a central advisory board whose members would be genuinely independent of the banks they serve (TKBB 2014, 71 and 74). ${ }^{7}$

Most observers doubt even that the Islamic banks avoid interest in their basic lending operations. Generally they do not lend through genuine profit and loss sharing. Rather, they resort to resale contracting (Turkish, murâbaha; Arabic, murābaha), a method that allows the charging of interest in disguise. Under resale contracting the bank pretends to buy an object on behalf of a client, who agrees to purchase it at a higher price payable in the future. Because the bank's ownership lasts a few moments, the double transaction is effectively equivalent to a simple loan at interest. ${ }^{8}$ For credit card transactions, Turkey’s Islamic banks rely exclusively on resale contracting.

The ruses of Turkey's participation banks have precedents in Ottoman economic life. As in other states governed under Islamic law, in the Ottoman Empire Islamic courts ratified and upheld interest-based contracts provided interest was disguised through a euphemism that made it look like rent or payment for a side transaction. ${ }^{9}$ Lending at interest was common because it economized on monitoring and computation costs. It is for the same reasons that today's participation banks base an overwhelming share of their commercial lending operations on interest rather than profit and loss sharing. Setting a fixed payment avoids the

\footnotetext{
${ }^{6}$ The officials of Islamic banks say that although the sharia boards are not required to reach a consensus on every matter, any difference of opinion meets with sustained efforts to make dissenter(s) join the majority. Consequently, board opinions are almost always unanimous.

${ }^{7}$ Cross-memberships also endanger the mutual independence of the banks. But the risks are currently low, because the board members do not get involved in management.

${ }^{8}$ Turkey's participation banks also use several other methods for disguising interest (Y1lmaz, 2010, 11).

${ }^{9}$ See Kuran ed. (2013) for hundreds of seventeenth-century legal cases that involved interest.
} 
trouble of having to monitor the borrower's accounts. By minimizing the probability of disagreement over what is owed, it also economizes on litigation costs.

The 2001 collapse of İhlas supports the observation that Islamic banking differs only cosmetically from conventional banking. Had İhlas been paying its depositors profit shares rather than interest, and had its depositors accepted the riskiness of their deposits, it could have stayed afloat simply by passing its investment losses onto its depositors. The latter could have been told that, after many years of positive returns, the bank's investments had soured, causing deposits to shrink. İhlas would have stayed afloat because its revenue losses would have been matched by declines in its obligations. In fact, the depositors of İhlas did not behave as patient shareholders. By rushing to withdraw their deposits, they compounded their bank's insolvency. Although certain İhlas depositors might have been committed to profit and loss sharing on religious grounds, the majority simply saw it as a financial intermediary operated by practicing Muslims according to rules essentially identical to those of conventional banks. ${ }^{10}$ They responded to İhlas' distressas they would have responded to signs that their deposits at a conventional bank were in danger. ${ }^{11}$

The regulatory response to the collapse of İhlas Finans amounted to official confirmation that the customers of Turkey's Islamic banks view their deposits as functionally identical to deposits in conventional banks. By insuring deposits at participation banks, bank regulators acknowledged that most Islamic bank customers expect their deposits to be protected and that they are not interested in genuine profit and loss sharing. The regulators signaled also that the Islamic banks themselves value market share more than doctrinal purity. After all, the Islamic banks are always free to serve the few pious customers who are genuinely committed to keeping their financial transactions free of interest. Precisely because the demand for genuinely interest-free finance is negligible, the Islamic banks saw deposit insurance as essential to their viability. They understood that to maintain a significant presence in the Turkish banking sector, and certainly to expand their shares, they had to make their products look more like those of their conventional competitors. The adaptation amounted, of course, to a formal abandonment of the Islamic principle of financial risk sharing.

\footnotetext{
${ }^{10}$ The customers of the other Islamic banks generally shared these perceptions. Most of Turkey's heavily Muslim population sees no difference in substance between the country's conventional and Islamic banks. That is one reason why the share of Islamic banks in Turkey's banking sector remains around six percent after more than a decade of rule by a political party sympathetic to Islamic banking.

${ }^{11}$ The former clients of İhlas, known collectively as "victims of İhlas" (Ihlaszedeler), continue to pressure the government for compensation through Facebook and Twitter. The postings on these social media underscore that they never really agreed to share in losses (Haber7com, 2006).
} 
In sum, three decades after the opening of Turkey's first Islamic banks, and more than a decade after a party sympathetic to Islamic finance came to power, the share of Islamic banks in the banking sector remains modest. Like their counterparts around the world, Turkey’s Islamic banks claim that their operations differ substantively from those of conventional banks. Yet, similarities between the operations of Islamic and conventional banks and dissimilarities among individual Islamic banks both suggest that Islamic banks are guided less by shared Islamic principles than by consumer demand.

\section{Turkey's credit card market and its Islamic credit cards}

Diner's Club issued Turkey's first credit cards in 1968. A Turkish Diner's Card provided credit on a short-term basis, in that the holder was required to pay his full balance at the end of the grace period specified on his monthly bill. Accepted at a few establishments catering to elites, it served more as a prestige symbol than as a source of credit (Schoell 2010, 33). Expanding tourism prompted American Express to enter the Turkish credit card market in the early 1970s. Eurocard, Mastercard, and Access followed in 1975, and Visa in $1984 .{ }^{12}$ To facilitate the settlement of transactions involving multiple banks, thirteen banks established an Interbank Card Center in 1990 (BKM, 2010, sect. 1). Before long, banks were promoting credit card use through bonuses tied to transaction volume.

As shown in Figure 1, by 200320 million credit cards were in circulation, and the number rose to 57 million by 2013 . Over the same period, the number of credit cards per capita jumped from 0.28 to 0.74 ; and the share of recorded transactions settled by credit card rose from 9.3 percent in 2002 to 21.7 percent in 2007, then reached 36.4 percent in mid-2013 (BKM, 2013).

Figure 1 here

The responsiveness of Turkey's Islamic banks to market pressures concerning the safety of their deposits suggests that, if only to remain competitive with their conventional rivals, they would have sought to incorporate credit cards into their operations. Indeed, İhlas Finans became Turkey's first Islamic bank to issue credit cards in January 1998 (Zaman, 1998). The remaining Islamic banks all followed suit within a few months (Albaraka Türk, 2012; Bank

\footnotetext{
12 Visa opened an office in Turkey in the same year (Kaya, 2009, 18). Mastercard did so in 1993 (Karahan and Çakmak, 2011, 33).
} 
Asya, 2013; Kuveyt Türk, 2012). ${ }^{13}$ Although these cards were touted as "credit cards," they all functioned as charge cards. The first bona fide Islamic credit card-one that allowed the holder to pay for purchases in installments—was issued by Bank Asya in 2002 (Bank Asya 2013). Kuveyt Türk issued its own genuine credit card in 2004; in addition to installment purchases, it allowed cash withdrawals (Y1lmaz, Öz, 2004). In the course of these developments, Turkey's Islamic banks banks joined international credit card organizations such as Visa and Mastercard. ${ }^{14}$

It is qualms about interest that delayed the Islamic banks' entry into the credit card market. Once they overcame their inhibitions, they gained market share steadily. In 2003, their share in terms of card numbers stood at 0.1 percent. As they added conveniences, particularly the right to delay payments, their popularity grew. By 2013, the Islamic banks' share had increased thirty-fold to 3.2 percent (Table 3). Over the same period, their share of all credit grew more modestly, from 4.5 to 6.1 percent. $^{15}$

Table 3 here

Although all four of Turkey's Islamic banks issue credit cards, Bank Asya holds a commanding lead in terms of both customers and issued cards. As Table 4 shows, 58.1 percent of the holders of Islamic credit cards have an Asya credit card, and 63.1 percent of all active Islamic credit cards belong to Asya. Asya happens to be the leading Islamic bank as measured by assets, deposits, and total credit as well. But its dominance is not nearly as great in regard to other measures. It issues 30.6 percent of the Islamic banks' total credit, including commercial loans, mortgages, vehicle loans, personal loans, and credit card debt.

Table 4 here

\footnotetext{
${ }^{13}$ In its 2012 annual report Kuveyt Türk claims that it issued Turkey's first Islamic card. This is a valid statement only with respect to the Islamic banks that remained solvent through 1998.

14 İhlas Finans signed an agreement with Visa in 2000 (Türkiye, 2000). Kuveyt Türk followed in 2002 (Kuveyt Türk, 2012) and Bank Asya in 2003 (Bank Asya, 2013a).

15 The drops in 2013 stem from deposit withdrawals and credit card returns to one of the four Islamic banks, Bank Asya, which is widely known to be owned and operated by followers of the Pennsylvania-based cleric Fethullah Gülen. Once allies, Prime Minister Recep Tayyip Erdoğan and Gülen became archenemies in 2013, and their quarrels reached a climax with the Gülenist-led corruption investigation of Erdoğan's close circle. Bank Asya lost no fewer than 850,000 credit card customers by the end of the year, largely because of an Erdoğan-ordered boycott of Gülen establishments. On February 3, 2015, Turkey's state-run Savings Deposit Insurance Fund (TMSF) took over the management of Bank Asya and gained control of 63 percent of its privileged shares.
} 
Table 4 indicates that the participation banks differed in the degree to which they built up their credit card business. Bank Asya's share of the Islamic credit card market is double its share in Islamic credit operations as a whole. The highly skewed distribution in the Islamic credit card market reflects differences among the service packages offered. As Table 5 shows, the two banks with the lowest shares require credit cardholders to settle their entire monthly bill by the end of that month's grace period. By contrast, Asya and Türkiye allow cardholders to rollover more than half of each month's bill. Along with Kuveyt Türk, these two banks also allow cardholders to convert accrued payment obligations into installment plans. Under an installment plan, the purchaser of a good can opt to settle his bill over 36 months, paying 1/36th of the bill each month, plus a "profit share."16 Islamic banks also allow cardholders to spread the charge for individual transactions over time through their bonus schemes. In a bonus scheme the customer pays no mark-up to the bank. The seller of the product provides an installment option as a way of promoting sales. Ordinarily, any interest charges are included in the good's price. As noted earlier, the bonus plans differ in terms of the set of companies where points may be converted into goods or services. Yet another difference across the plans concerns cash advances. Only two of the banks offer this privilege. ${ }^{17}$ Islamic credit cards differ also in terms of assistance provided to travelers and special discounts at select stores. Certain credit cards are equipped with electronic chips that point to Mecca. All four Islamic banks allow cardholders to pay for pilgrimage expenses in 36 installments. ${ }^{18}$

Table 5 here

Table 5 reconfirms that no Islamic bank offers a credit card featuring all the conveniences of a conventional credit card. Once again, that is why the Islamic banks have captured a lower share of the credit card market than of the market for credit in general. The differences among the four banks shows that the customers of Islamic banks care about the range of services offered by competing credit cards. Asya's heavy dominance and Türkiye's second place position suggest that the most valuable service of a credit card is the ability to

\footnotetext{
${ }^{16}$ Effective February 1, 2014, the government banned the use of installment plans with regard to telephone bills, taxes, grocery purchases, fuel charges, insurance premia, and jewelry purchases (YapıKredi, 2014).

${ }^{17}$ Ordinarily advances are limited to 10 percent of the cardholder's credit limit or TL 500, whichever is smaller. Türkiye Finans does not charge for advances, though payment in full is required within the grace period. Kuveyt Türk charges TL 1.25 as a transaction fee and inflation compensation (enflasyon farkl). Kuveyt Türk's "seyyah" card allows pilgrims in Saudi Arabia to withdraw cash up to 50 percent of the credit limit.

${ }^{18}$ This privilege has generated controversy (Son Kale, 2012).
} 
spread payments over time without bothering with installment plans for each purchase. This interpretation accords with market surveys showing that Turks consider access to installment plans the most attractive feature of a credit card (Bankalararası Kart Merkezi, 2012).

\section{Services and fees of Islamic credit cards}

Imagine an Islamic credit card holder who buys a refrigerator on November 1, charging the cost of TL 1000 to his Türkiye Finans Gold card. The store delivers the refrigerator to the cardholder, who begins to enjoy its use. The TL 1000 charge shows up on the monthly Türkiye Finans statement of the cardholder, who has until December 1 to pay in full to avoid late fees. Technically, Türkiye Finans still owns the refrigerator. The cardholder chooses to make only the minimum payment of TL 100, whereupon Türkiye Finans adds to his January 1 bill a "profit share fee" (kârpayı oranı) of TL 18.18, or 2.02 percent of the unpaid amount of TL 900. ${ }^{19}$ The cardholder now owns a tenth of the refrigerator and Türkiye Finans the remaining nine-tenths. The bank resells the nine-tenths upon receipt of the minumum payment, and the cardholder receives a bill for TL 918.18 on January 1. If the cardholder pays this amount in full, he will become the refrigerator's sole owner, and nothing more will be due. If not, the cycle will continue, and a new "profit share fee" will go on his February 1 statement, along with his unpaid balance. In effect, the customer buys the refrigerator on Türkiye Finans credit and pays his bank a periodic fee on upaid portions of the loan. The periodic fee is tied to both the cardholder's balance and his last payment date. The economic term for such a fee is interest.

After buying the refrigerator and receiving delivery, the cardholder takes his family to a restaurant. Suppose that he pays the dinner bill of TL 200 through the same Türkiye Finans card. The fiction that was plausible in the case of the refrigerator purchase will now strain the imagination. By the time the waiter brings the bill, the food is all consumed. Buying consumed food on behalf of the customer is not feasible. In the case of perishable goods, therefore, it is impossible even in principle to split the transaction into two: a quickly paid service that the restaurant provides to the bank, and a contract between the bank and the cardholder. Whereas a refigerator can be repossessed from a delinquent payer, consumed perishables cannot. Nevertheless, the Islamic banks rely on the same fiction to disguise their interest charges. They thus conceal that with respect to diverse goods and services on which

\footnotetext{
${ }^{19}$ In November 2013 the prevailing monthly fee for "TFKB Gold Kart" holders was 2.02 percent (BDDK, 2014).
} 
they allow payment by credit card, their fees amount to interest on a cash advance. In addition to perishables, this broad category includes medical treatments, legal services, home repairs, education, hotel stays, and travel.

As the family dinner concludes, our cardholder tips the waiter in cash and notices that he is running low. His wife points to a cash machine across from the restaurant. Their checking account happens to be depleted, so he decides to draw money from another credit card in his wallet, a Kuveyt Türk Sale Plus Gold Visa. Inserting the plastic card into the machine, he receives TL 300. This amount will appear as a charge on his next Kuveyt Türk statement. In this third transaction of the day, the fiction of commodity resale fails entirely. Involving no physical commodity, it is simply a currency loan dispensed through an unattended machine rather than a flesh-and-blood teller. In addition to a one-time service fee for the transaction, he starts paying a time-dependent charge on TL $300 .{ }^{20}$ The accrual of charges will stop only when he pays a monthly Kuveyt Türk bill in full.

At the end of a long day, our cardholder attends to a few household chores. The motor vehicle tax (motorlu taşıtlar vergisi) on the family car is due, and it can be paid online. Reaching the site, he notices a Bank Asya advertisement. It announces that yet another credit card in his wallet, Asya Visa Gold, allows payment in three installments (Bank Asya, 2013b). Provided he makes the monthly payments on time and in full, there will be no charge. Yet, there will be a fee on portions of the tax that are not paid on schedule. The cardholder will start accruing periodic finance charges that vary with both the unpaid amount and the length of the delay. These charges constitute interest.

Over and above the fees they incur for specific transactions, almost all Islamic card owners pay an annual fee to the issuing bank. As with a conventional credit card, the amount depends on the services offered. For a basic Islamic card, the fee is usually low, sometimes even nil. For a gold or platinium card, it can be substantial.

In two essential respects, then, Islamic credit cards substitute closely for conventional credit cards. They offer the same range of services. They also charge similar fees for particular services, though generally under different names. For a merchant, too, the two types of credit card function similarly. When a customer pays for a good through an Islamic credit card, the merchant pays a service fee to the issuing Islamic bank. Moreover, if he desires immediate payment - the day after the transaction, as opposed to a month later- he pays a "timedependent commission."

\footnotetext{
${ }^{20}$ Kuveyt Türk calls the time-dependent charge an "inflation differential" (enflasyon farkl).
} 


\section{Doctrinal controversies}

As credit cards became an increasingly significant source of revenue for conventional banks, it was only natural that Islamic banks would want to issue credit cards themselves. Their challenge was to meet Sharia requirements without giving up the characteristics that make credit cards popular. The task of finding acceptable solutions fell to the Sharia boards of the Islamic banks. The members of these boards sought to justify the use of credit cards through methods of Islamic jurisprudence that have been in use for more than a millennium. Thus, they tried to legitimize the credit card through principles extracted from the Qur'an, the Sunna (recollections of Muhammad's words and deeds), and ijma (consensus among themselves). On certain matters, the boards of Turkey's Islamic banks quickly gave their endorsement. Other matters proved controversial. Opinions have differed across boards and, with each board, across time.

Certain charges imposed on credit card holders posed no problem from an Islamic standpoint. The periodic management fee that a credit card issuer charges its customers is legitimate under even the strictest interpretation of Islamic law. Likewise, the commission that a bank collects from a merchant who accepts payment by credit card is compatible with Islamic law, provided its magnitude is independent of the payment date. ${ }^{21}$ In and of itself, charging a commission for financial intermediation does not transgress any Islamic principle. Thus, when Turkey's Islamic banks began to consider offering credit cards, Turkish Sharia experts were quick to declare that membership fees and merchant commissions pose no problems from a religious standpoint (Aktepe, 2010, 111-123). ${ }^{22}$

What was potentially problematic to ostensibly interest-avoiding banks was the deferral of cardholder payments. If a cardholder fails to pay her balance at the end of her grace period, or she opts to pay in installments, how would her obligations to the bank be affected? An obvious solution, implemented by the issuers of conventional credit cards, is to charge interest on unpaid balances. Alas, Islamic banking treats interest as sinful. Precisely for that reason, most Islamic scholars consider it un-Islamic even to own a conventional credit card, simply because it allows the deferral of payment for interest. It is unacceptable to possess a conventional credit card, they say, even if one avoids interest charges by paying the full amount within each grace period (Aktepe, 2010, 113-114; AAOIFI, 2012, 68; Bakhshi, 2006, 21). A minority view is that one may use a conventional card provided balances are never

\footnotetext{
${ }^{21}$ If the intermediating bank were to discount its payment to the merchant to reflect the card holder's deferred payment to the bank, interest would be involved, and the "commission" would be impermissible (haram) (Şahin 2009).

${ }^{22}$ Pertinent religious opinions (fetvas) include Karaman (1998a, 1998b) and Şahin (2006).
} 
rolled over (Bakhshi, 2006, 20). According to the latter interpretation, Islamic banks may issue credit cards simply by removing the payment deferral option. Requiring cardholders to pay monthly balances in full would eliminate the need for extra charges.

Let us reconsider the procedures of lending through credit cards with an eye toward spotting factors potentially incompatible with the Sharia. When a shopper attempts to charge a good to a credit card issued by a certain bank (call it A), the seller verifies the card's validity and the sufficiency of its credit line. The verification is done through a point-of-sale (POS) machine belonging to a bank at which he has an account (B). Once the credit is verified, the transaction is complete. The shopper will see the charge on his monthly statement from Bank A, which charges an annual fee for the provision and management of his credit. Provided the shopper pays his bill in full within the 20-25 day grace period, he will incur no further charges. Regardless of whether the shopper's payment arrives on time, at the end of the grace period Bank A will deposit the full amount of his charge into the seller's account at Bank B. A third party executes the settlement between the two banks for a commission. For domestic transactions this third party is usually Turkey's Interbank Card Center. Sometimes it is an international credit card company, such as Visa or Mastercard. These two foreign companies also handle all international transactions.

From the start, the Sharia boards of Turkey's Islamic banks considered the foregoing transactions perfectly legitimate. They all involve one party selling a good or service to another, they said, for a mutually agreed charge, fee, or commission (Aktepe, 2010, 111-123; AAOIFI, 2012, 73-74). They amount to permissible returns to trade, which the Qur'an and the Sunna both promote widely. ${ }^{23}$ Of course, the object of the transaction would itself need to be compatible with Islam. Buying a good whose consumption is banned—wine, blood, carrion, pork, non-halal beef — is intrinsically illegitimate, regardless of payment form. The same applies to activities that Islamic scholars consider un-Islamic, such as discotheque entertainment and gambling. There is a consensus that Islamic credit cards should not be used for transactions incompatible with Islam.

It is technologically possible to program a credit card to deny charges involving banned goods and services. But no Islamic card issued in Turkey or elsewhere is equipped with such a filtering procedure, which raises the question of whether the cards are inherently un-Islamic. After all, a cardholder may purchase non-halal beef as part of an otherwise

\footnotetext{
${ }^{23}$ Verse 4:29 of the Qur'an offers an example: "Believers, do not consume your wealth among yourselves in vanity, but rather trade with it by mutual consent." For another illustration, Muhammad, who was a merchant himself, is reputed to have said that "the honest and trustworthy merchant will be judged in the class of the prophets, the truthful, and the martyrs" (quoted in Aktepe, 2010, 23).
} 
Sharia-compliant supermarket purchase. The consensus is that the possibility of using an Islamic card for un-Islamic purposes does not undermine the card's Islamic legitimacy. Just as crooks put money itself to illegal uses, so the holders of Islamic cards may include people who abuse their privileges (Aktepe 2013, 137). Besides, abuses carried out through an Islamic credit card can also be executed through cash. One can pay cash for non-halal beef.

The seller is entitled to payment at the end of the buyer's grace period. For its part, the card issuer will want to be paid for its intermediation. Suppose, then, that Bank A withholds 2 percent of the charge and deposits the remaining 98 percent to the seller's account at Bank B. On the view that the withheld amount represents a service commission, most of Turkey's Sharia scholars consider it Sharia-compliant. In fact, they hold that merchants can accept a commission-charging credit card without qualms on any halal transaction, even if the card is issued by a conventional bank (Şahin 2009). What if the seller requests payment before the end of the grace period in question? In this case, the card issuing bank will want to increase its commission to reflect the time value of money. This is a common practice among conventional banks. Although the extra commission amounts to interest, all of Turkey's Islamic banks follow the same practice. They do so even though Turkey's highest religious body (Diyanet İşleri Başkanlığı) has ruled the practice un-Islamic (Sorularla İslamiyet, 2003).

Consider now the case where the cardholder pays Bank A after the grace period. Suppose that the bank charges a mark-up for the delay. In this case, the fee is linked directly to the timing of the payment, as the cardholder could have avoided it by paying within the grace period. Indeed, Islamic scholars treat this fee as interest which, in their view, violates the Qur'anic ban on riba. ${ }^{24}$ Prophet Muhammad, they say, "cursed" everyone involved in interest transactions: payers, receivers, recorders, and even witnesses (Aktepe, 2010, 23). On these grounds, Sharia scholars consider the practice of rolling over credit card debt for a fee to conflict with fundamental Islamic teachings. ${ }^{25}$

The holder of a credit card could use it cautiously enough to ensure that he pays in full within the grace period. Among other Turkish Sharia scholars, Hayrettin Karaman, who sits on three Sharia boards, believes that it is legitimate to use any credit card, even a conventional one, if one avoids the need to pay interest (Karaman, 1998a). ${ }^{26}$ But most Turkish Sharia scholars favor a stricter standard. They find it sinful to agree to an interest charge for delayed

\footnotetext{
${ }^{24}$ See especially Qur'an 2:275-79, 3:130, and 30:39.

${ }^{25}$ For Turkey see Aktepe (2010) and Şahin (2009). For other countries, see Visser (2009), 66.

${ }^{26}$ Bakshi (2006), 20-21, Y1lmaz (2001), 87-88 express the same view.
} 
payment, regardless of whether one intends to spread payment over time (Aktepe, 2010, 113; Y1lmaz, 2001, 88-89).

It is this categorical opposition to conventional credit cards that generated a search for Sharia-compliant substitutes. The simplest alternative was to remove the charge for late payment. Some Sharia scholars favored this solution on the pretext that Islam calls for compassion toward debtors in distress. ${ }^{27}$ Good Muslims would pay on time when possible, was the reasoning; only under extenuating circumstances would they delay payment. Besides, any charge for late payment, regardless of the form, would amount to riba. Other Sharia scholars found this solution impractical. For one thing, unscrupulous customers would exploit the absence of a late payment charge. They would feign hardship to shift consumption forward, possibly even to escape payment altogether. For another, uncompensated delays could impose an unbearable opportunity cost on the credit card issuer. Unable to recirculate its capital, it would suffer a fall in profits; if delays became sufficiently common, it could even be forced out of the credit card business.

Among the pragmatic scholars who comprise the latter category is İshak Emin Aktepe, who merits an extensive quote:

Where necessary for the creditor to receive his due, the debtor may be punished. Sources of Islamic law do not specify the punishment. In effect, they defer to the judgment of state officials.

In today's states and contemporary commercial life the penalties prescribed by past Islamic scholars are infeasible. In any case, they may result in serious harm. To blacklist a firm that has failed to settle a debt on time would be to force it into bankruptcy. Breaking its ties to banks and invalidating its checks would produce the same effect. A small mistake would thus draw a disproportionate punishment. By the same token, the creditor should not be asked to simply put up with the debtor's delay. In particular, companies that earn returns by investing funds collected from thousands of depositors cannot be expected to prevent delays on their own. Creditors have a legitimate right to demand compensation for inflation-caused losses associated with late payments. If a debtor pays late without accounting for inflation, he ends up harming his creditor in proportion to the consequent loss in purchasing power. When a debt contract is being negotiated, the creditor may legitimately seek

\footnotetext{
${ }^{27}$ Qur'an 2:280: "If your debtor be in straits, grant him a delay until he can discharge his debt; but if you waive the sum as alms it will be better for you, if you but knew it."
} 
protection from delays by insisting on converting the debt to gold or some foreign currency at the prevailing exchange rate.

However, in the case where the transaction is carried out in terms of gold or another currency, either the creditor or the borrower will endure risk. Certain modern scholars of Islamic law hold that when the borrower delays payment without a valid cause he is obligated to compensate the creditor for actual or possible damages caused. For example, if the creditor has endured expenses because of the delay, he is entitled to collect damages from the borrower. He may also collect the profits that he was likely to have earned had the borrower made payment as contracted. This, too, represents compensation for damages. ...

Borrowers who have a good reason for delaying payment should be given extra time. However, to protect borrowers who simply take advantage of the creditor would cause harm to the latter. He had been waiting for a while for settlement of his loan. It would compound his cost to make him endure also a loss for the damage caused by the delayed repayment. Islamic law does not legitimate damages on the basis of contingent or ambiguous interpretations. Delinquent borrowers without a cause should be penalized appropriately. The penalty may well be financial. The penalty that the state specifies for late payment does not constitute interest (Aktepe, 2013, 137-38, authors' translation). ${ }^{28}$

The inescapable implication of Aktepe's reasoning is that the feasibility of Islamic credit cards depends on some form of late payment charge. The charge may be justified as compensation for the creditor's foregone profits. Alas, the pragmatists disagree as to whether the "foregone profits" should be pre-specified. One side holds that setting the charge in advance of the payment delay would turn the charge into interest. Besides, foregone profits are unknowable exactly until the relevant opportunities have appeared (Bayındır, 2001, 59; Aktepe, 2010, 135-137). Invoking the need for transparency, which Islam also promotes, the other side argues that the cardholder will be burdened with undue uncertainty unless he knows of the bank's opportunity cost while deciding when to settle his credit card debt (Hayrettin Karaman, as recorded by Aktepe, 2010, 137-138).

\footnotetext{
${ }^{28}$ For similar opinions, see Y1lmaz (2001), 93-94.
} 
As discussed in previous sections, Turkey's Islamic banks all opted to penalize late payers at predetermined "profit rates." Implicitly, therefore, they have acknowledged that interest charges for late payment serve the needs of both the credit card issuer and the cardholder. By the same token, most Sharia scholars find current practices unsatisfactory. Some of them consider "profit rates" tainted. For that reason, they want these earnings to go to charity. Although Kuveyt Türk claims to do just that (Öztürk, 2013), this has not been verified. Certain observers consider the charity programs of Kuveyt Türk and other Islamic banks shady (Parker, 2010). Another indication of qualms about "profit rates" is that the charges that Islamic banks apply to unpaid balances lie below the interest charges of conventional banks. ${ }^{29}$ This points to an effort to limit the use of an instrument that remains suspect under practically all interpretations of the Sharia. Lowering "profit rates" has the effect, of course, of encouraging card holders to delay their payments. But Turkey's Sharia scholars have not yet addressed the tradeoffs involved.

Much of the early debate among Turkish Sharia scholars was based on the expectation that the holders of Islamic credit cards would generally make their payments within the grace period, delaying only in emergencies. This expectation rested on two implicit assumptions regarding the characteristics of Islamic cardholders. Unlike the holders of conventional credit cards, those of Islamic cards would eagerly avoid interest. Moreover, they themselves would view the "profit rates" of the Islamic banks as too similar to interest for comfort. It followed that the practical effects of penalizing late payment would be very limited. For most Islamic card users, Sharia scholars thought, the question of dealing with delayed payment would be moot.

It did not take long for the banks' Sharia boards to realize that their customer profile resembles that of conventional credit card issuers. In particular, they quickly learned that the holders of Islamic cards are willing to live with a revolving balance that can be settled over time with a surcharge. If it bothers their customers that the surcharge mimics interest, their unease is trumped by the conveniences of spreading payments into the future. Meanwhile, it became abundantly clear that Turks of all walks of life treasure the option of paying for purchases through installments (BKM, 2012). The Sharia boards had to revisit the treatment of revolving balances.

\footnotetext{
${ }^{29}$ In October 2013 all conventional banks charged interest at a 2.52 percent monthly rate to their late paying credit card customers. All four Islamic Banks charged lower rates. Albaraka was at the bottom with 1.69 percent (Türkiye Cumhuriyeti Merkez Bankası, 2013).
} 
As noted earlier, the solution that emerged was to treat credit card purchases as resale contracts akin to murabaha, an early Islamic contract often used to conceal interest (Karaman 1998a, 1998b; Aktepe 2010). ${ }^{30}$ Specifically, the issuer of the card would buy a good on the customer's behalf at the spot price and then sell it to the customer at a pre-specified markup. The cardholder would repay the bank in installments or in a lump sum after a certain period of time. In practice, of course, the Islamic bank would not be involved in the physical transaction. The transaction would be between buyer and seller. Yet the cardholder would serve as the bank's agent. In this capacity, he would first make the purchase from the merchant in the name of the bank, then sell the purchased commodity to himself at a markedup price, possibly according to an installment plan. Technically, neither of these paired transactions involves interest. But jointly they are equivalent to an interest-based transaction. Although the Sharia boards of Turkey's Islamic banks have all endorsed the use or murabaha, various Sharia scholars view it as a veil for riba. ${ }^{31}$

The practice of treating the cardholder as the bank's agent has also drawn objections. Abdülaziz Bayındır (2009) explains:

The installment plans of the interest-free banks depend critically on the cardholder's purchasing goods and services on behalf of the bank and selling then them to himself. This is un-Islamic. The Qur'an (4:29) says: "Believers, do not consume your wealth among yourselves in vanity, but rather trade with it by mutual consent." The verse makes clear that a sale must be between two individuals. The Islamic Fiqh Academy has ruled that in a murabaha transaction a person cannot serve as both buyer and seller: "An interest-free bank may authorize a customer to buy goods on its behalf. But it is more appropriate for the power of attorney to be given to someone other than the customer himself. Also, the bank must reach a new contract with the customer after it has purchased and taken possession physically of the goods in question." In the installment sales of some banks, certain necessary steps are purely fictional.

Another controversy concerns the practice of proposing an installment plan for sales already completed. The Islamic banks claim that it, too, mimics murabaha. Yet, under murabaha the financing party buys the good and then sells it to the consumer at a marked up price. In this case, by the time that the installment proposal reaches the cardholder's phone,

\footnotetext{
${ }^{30}$ For broader applications of murabaha and its history, see Kuran (2004), 7-12.

${ }^{31}$ For various criticisms, see Aktepe (2010) 117-118.
} 
the good has already been bought. Hence, the bank's message amounts to a debt refinancing proposal. $^{32}$

The Islamic banks' Sharia boards have had to address the issue of whether liquid assets such as gold, silver, and precious stones are purchaseable on credit. A remembered saying of Prophet Muhammad, "gold for gold, silver for silver, like for like, hand to hand, and whoever increases or asks for increasing, he commits riba," is generally interpreted as limiting the exchange of liquid assets at spot prices (Sabah, 2013; Kalender, 2010). Some scholars exclude jewelry such as earrings and rings on the ground that they are substantially less liquid than gold (Y1lmaz, 2001, 96-97). Whatever the disaggreements over the limits of restrictions concerning liquid assets, until recently many jewelers selling gold were equipped with POS machines belonging to an Islamic bank. Their customers were able to charge gold to an Islamic credit card. The jeweler would add the card's seller commission to the buyer's bill, and, for an additional fee, the buyer could pay for his gold purchase in installments. In February 2014, the use of credit cards for precious metal purchases was ended through a government decree designed partly to curb speculation and international money laundering. ${ }^{33}$

Receiving money for a larger amount in the future is a form of riba according to the remembrance just mentioned. Thus, all Sharia boards of Turkey's Islamic banks find it unIslamic to obtain a cash advance at interest through an ATM machine. But they have come under great pressure to accommodate the needs of their cardholders in urgent need of cash. Their response has been to allow cash advances to their customers on an interest-free, though limited basis. The legal justification has been the "benevolent loan" (qard al-hasana) principle of Islamic finance. In early Islam the wealthy were encouraged to offer, in addition to alms, benevolent loans to people in distress, expecting the recipient to repay only the principal. The Sharia boards now interpret distress more broadly than Muslim jurists of the seventh century; they recognize that a cash advance is rarely taken to feed a hungry child. In allowing banks to profit from the service, they are also interpreting benevolence more liberally. Although interest charges on cash advances are disallowed, banks may charge a fixed fee (Aktepe, 2010, 121-122). For any given service commission, the bank can ensure that it profits from an advance by setting a sufficiently low cash limit. ${ }^{34}$

\footnotetext{
32 Turkey’s Religious Affairs Directorate (Diyanet İşleri Başkanlığı) has been trying to help the Islamic banks resolve the controversy. On 5 May 2014 it even held a worshop on the matter (Din İşleri Yüksek Kurulu Başkanlı̆̆ı, 2014).

${ }^{33}$ Among the government's other motivations were the trimming of Turkey's current account deficit, raising the saving rate that had fallen to 12.6 percent, and reducing cardholder indebtedness (Biter, 2014).

${ }^{34}$ Suppose that the fixed fee for a cash advance is set at $f$ in an environment where conventional banks are allowing cash advances at an interest rate of $r$ and no fixed fee at all. The cash limit $L$ at which the Islamic bank
} 
Sharia scholars realize that their rationales for prevailing practices leave many Muslims unconvinced. To profide comfort, they offer also general justifications aimed at alleviating qualms about financial practices for which early Islamic precedents do not exist. The most common general justification is based on Qur'an 2:185: “Allah desires your wellbeing, not your discomfort." This verse lies among several prescriptions concerning the requirement to fast during Ramadan. It permits travelers and the sick to postpone their fasting obligations. Like many earlier innovators stretching back to the Middle Ages, Sharia scholars focused on credit card practices have opted to interpret verse 2:185 as a broad call for using reason to allow conveniences unimaginable in the seventh century. This verse allows them to concoct Islamic variants of new financial products that gain popularity.

It may seem that Sharia boards would be partial toward religious consumption. Indeed, they have encouraged pilgrimages (hajj) and animal sacrifices by allowing their costs to be paid in installments. But these practices have been controversial. Islamic customs impose the pilgrimage duty only on adults who are able to finance all requisite expenses on their own and without harming their dependents. In the view of a small minority of Turkey's Sharia scholars, someone is ineligible for the pilgrimage if it requires him to borrow. They add that the privilege of animal sacrifice belongs only to people able to finance the cost up front (Vatan, 2004; Vatan, 2008).

As interesting as the prevailing controversies is what receives quiet acceptance. Credit cards promote not only religious consumption but consumption in general. A large literature shows that they encourage impulsive buying and that they conceal tradeoffs among alternative spending options. ${ }^{35}$ For these reasons, one might expect Sharia scholars to view them as unIslamic instruments of wasteful consumption. The Qur'an condemns extravagance in numerous verses, such as 7:31: “Children of Allah, dress well when you attend your mosques. Eat and drink, but avoid excess. He does not love the intemperate. ${ }^{\prime 36}$ On that basis, Islamic economists place moderation in consumption and waste minimization among the distinguishing features of Islamic economics. Alas, except when used strictly as a charge card, a credit card encourages consumption by allowing spending beyond one's means. It permits

earns just as much as the conventional bank is given by $L(1+r)=L+f$. Rearranging yields $L=f / r$. An Islamic bank that sets its cash limit at $f / r$ would earn more than the conventional bank from customers that withdraw less than $L$.

${ }^{35}$ Gross and Souleles (2002) find that an increase in a credit card's limit generates a significant rise in the holder's consumer debt. Based on genuine auctions, Prelec and Simester (2001) show that consumers' willingness to pay may increase up to 100 percent when they are instructed to use a credit card rather than cash. Using a model that allows mental compartmentalization, Prelec and Loewenstein (1998) find that credit cards stimulate consumption by enabling consumers to enjoy the benefits of purchases without feeling the costs fully. ${ }^{36}$ Others include 4:6, 6:141, and 25:67. 
the holder to make purchases that would be considered ostentatious for someone of his income.

Hence, in advertising their credit cards and encouraging their customers to own one of their cards, Islamic banks effectively encourage compulsive spending rather than cautious shopping, and immediate gratification as opposed to responsible budget management. They turn Islamic banking into an element of the consumption-driven market economy that Islamic economists consider unethical and, specifically, un-Islamic.

Turkey's conventional banks have long encouraged the use of their credit cards through bonuses tied to spending amounts. The Islamic banks initially avoided bonus programs on the ground that they violate Islam's principle of moderation. Before long, in a bid to gain competitiveness, they switched track. Asya and Kuveyt Türk developed bonus programs of their own. For their part, Albaraka and Türkiye Finans opted to join already popular programs started by conventional banks. ${ }^{37}$ Two of these four banks, Asya and Türkiye Finans, are even encouraging the use of their cards through mobile phone messages that allow holders to convert an initiated or completed charge to an installment plan. By pushing back payment obligations, this option raises consumers' immediate purchasing power, thus making them spend more. ${ }^{38}$

The effects of credit cards in stimulating consumption have received practically no attention in the Turkish literature on Islamic credit cards, where the dominant theme has been the charging of interest. Not even the bonuses provided by Islamic credit cards have drawn criticism, even though they are designed to make card holders spend more; they might have been treated as instruments of overconsumption. Leading Islamic scholars have explicitly bestowed their approval (Aktepe, 2010, 122; Karaman, 2009). ${ }^{39}$

In a nutshell, Islamic credit cards contribute to the pathologies of the conventional credit card industry because they provide essentially the same services. This raises the question of why, having been launched as a superior alternative to conventional credit cards, Islamic credit cards have morphed into branded replicas as opposed to substantively novel financial

\footnotetext{
${ }^{37}$ Each bank's website offers information about its bonus program. BonusCard and WorldCard are the most popular bonus programs. They were initiated by major conventional banks, Garanti and Yap1 Kredi, respectively. Türkiye Finans joined BonusCard in 2009 (Bonusnet, 2015) and Albaraka signed an agreement with WorldCard in 2011 (Bugün, 2011).

${ }^{38}$ For instance, in late 2013 after a purchase charged to a Bank Asya credit card, Asya would send the following text message to the holder's mobile phone: "To spread the payment of x TL across up to 36 months at a profit rate starting at $0.99 \%$ and a $1 \%$ fee, send the number of months space the confirmation number nnnnnn to 2792 " (x TL'lik işlemi aylı \% 0,99'dan başlayan kâr oranı ve \%1 ücretle 36 aya kadar bölmek için taksit adedi boşluk nnnnnn onay kodunu 2792 'ye gönderin). The " $x$ " in the statement corresponds to the charge just made, and "nnnnnn"to the six-digit confirmation number that accompanies the text message.

${ }^{39}$ See also Y1lmaz (2001), 99.
} 
instruments. The simple answer is that consumers like the conveniences of conventional credit cards. Islamic banks have adopted all key features of conventional credit cards in order to make their own cards competitive. To acquire and guard market share within the credit card industry and, more broadly, within the Turkish banking sector as a whole, they have shedded the "Sharia-compliant" characteristics of their cards, or opted to leave them unenforced.

This interpretation accords with the observation that market competition can destroy censured behavior. Competitive pressures, notes Andrei Shleifer (2004), can cause the spread of behaviors that are somehow unethical. The censure in question may well be compatible with efficiency. For example, an ethical norm against employing children may improve social welfare by ensuring that the future workforce is educated. Still, it can become unenforceable merely because its violators gain competitive advantages. If child labor is cheaper than adult labor, a firm can lower its costs by hiring children, thereby acquiring a capacity to reduce its prices. Simply to stay in business, its competitors may then be forced to hire children themselves. The same logic applies to the children's parents. If parents in one family make their children work, competition for food or status may induce other parents to place their own children in the workforce. In sum, competition on both the demand and supply sides of the labor market may erode an ethical norm when unethical behavior gives individual decision makers a competitive advantage.

\section{The global Islamic credit card market}

The legitimacy of various practices have divided Sharia scholars in other countries, too. Around the time that Turkey's Islamic banks were contemplating bona fide credit cards, world-renowned Sharia scholars were debating whether credit cards could be made Shariacompliant. One question was whether the conventional credit card had uses compatible with Islamic financial principles. Through online fatwas starting in 2001, Monzer Kahf, a SyrianAmerican Islamic economist and counselor, proposed that a conventional card gives its holder the option of avoding interest charges simply by paying bills within the interest-free grace period. It is permissible to hold a conventional credit card, he wrote in response to a query, "provided that you know for sure that you are keen and able to pay within the grace period without any delay and to abstrain from cash withdrawals" (Kahf, 2001, 1-2). Another prominent scholar, Muhammad Taqi Usmani of Pakistan, considers it permissible to use a conventional credit card for the same reason, that it does not necessitate the payment of interest. But the cardholder must have the issuing bank debit each month's charges from his 
bank account "to avoid the possibility of default, which may in some cases carry the risk of interest" (cited by Bakshi, 2006, 23).

Usmani's precautionary requirement does not provide a fail-proof method for avoiding interest. After all, if emergency expenditures lower his bank account sufficiently the automatic debiting will fail, resulting in an unpaid card balance and a commensurate interest charge. Usmani's critics observe that forgetfulness, sudden unemployment, or a health problem could generate interest obligations. In any case, say the critics, it is sinful even to consider signing a contract that requires paying interest under certain contingencies. ${ }^{40}$ It legitimizes, and helps to fund, an institution that Muslims should be trying to eradicate. Insofar as the ultimate goal is to purge interest from human civilization, Muslims should avoid credit cards and Islamic banks should not offer anything similar.

The objections to conventional credit cards have not kept them from spreading within the Muslim world. Table 6 shows that in both Malaysia and the Gulf, the trailblazers of Islamic banking, one conventional or Islamic credit card is in circulation for every four adults. While the number of credit cards per capita in these centers stands at one-sixth of the corresponding figures in the world's economically most advanced countries, they are almost double the average for Asia.

Table 6 here

The Arab Gulf and Malaysia were also the first to offer Islamic credit cards for the benefit of people who object to conventional credit cards. In the Arab Gulf, home of the world's first Islamic bank, ${ }^{41}$ Bahrain's Bank Shamil introduced the Shamil Card in 2002. In Malaysia, where Muslim-dominated governments have promoted Islamic banking vigorously to serve the economically trailing Muslim majority, Am Bank had already introduced what Malaysian Islamic bankers consider the world's first Islamic credit card. Launched in 2001, it was called the al-Taslif Card (Konsultasi Muamalat, 2007).

Arab Islamic bankers bestow the laurels on the Shamil Card on the ground that Am Bank collected interest from its cardholders. On their outstanding balances, al-Taslif holders paid 1.25 percent per month without compounding, or 15 percent per annum. The interest charges were disguised through resale contracting. A charge was treated as two sales, one from the merchant to Am Bank, the other from Am Bank to the cardholder at a higher price

\footnotetext{
${ }^{40}$ For several variants of this argument, see Bakshi (2006), 21-22.

${ }^{41}$ Dubai Islamic Bank, founded in 1975.
} 
(Konsultasi Muamalat, 2007). Arab Islamic bankers assert that the Shamil Card genuinely avoided interest through fixed charges unrelated to the size of individual transactions, or even to monthly or annual expenditures. The holder of a Shamil Card paid a flat five percent fee for a credit line, for which he also posted collateral. This allowed him to pay for his purchases in 12 monthly installments, without any surcharge. Likewise, the cardholder paid a fixed fee for cash advances, regardless of size (Konsultasi Muamalat, 2007). There was a catch, however. By capping the magnitude of any given cash advance and keeping the cardholder's credit limit sufficiently low, Bank Shamil put a floor under the effective interest rate that it would earn from its customers' transactions. ${ }^{42}$

The controversy over who introduced the first Islamic credit card reflects an enduring split in the Islamic finance community over the practical implications of the Qur'anic ban on riba. There is an Asian school, also called the Malaysian School because of Malaysia's prominence in Islamic banking, which is associated with pragmatism and flexibility. Its members are satisfied with procedures, such as those of Am Bank, that cleanse transactions of interest on paper. The other school, known as the Arab school, or more commonly the Gulf School, favors complex procedures that disguise interest charges more effectively. It is also relatively more restrictive as to what transactions pass as Islamic.

Called bai al-inah, the procedure of the Asian school makes the cardholder serve two roles at once: the issuing bank's agent and its client. In using his card to make a purchase, he conducts a pair of side transacations with his bank. Specifically, he sells the bank a fictitious asset for immediate payment, then repurchases it for payment later. As for paying the merchant, he does so through the cash that he receives from his bank. Seconds after these transactions, the bank offers the cardholder an installment plan at a higher total cost. If at the end of a grace period associated with a monthly bill he pays less than the full balance, he is charged a proportional fee called "profit rate."

As for Islamic banks in the Gulf School, they tend to use one of two procedures. One is called tawarruq, and it resembles bai al-inah. Three of Sunni Islam's four canonical schools of law consider these procedures identical. The Hanbali school, which is predominant in Saudi Arabia and Qatar, sees a difference. In tawarruq, according to the Hanbali formulation, the bank does not exchange any good or service with the cardholder directly. Rather, transactions occur between the cardholder and a fictitious third party, with the bank serving

\footnotetext{
${ }^{42}$ See note 34. Shamil's cardholders who spent up to their credit limit and took the largest possible cash advances, paid the lowest effective rates. The less they spent or borrowed, the higher their effective rates.
} 
them as an intermediary (Bakhshi, 2006). The postulation of a third party complicates the identification of interest by increasing the number of imagined transactions.

The other procedure of the Gulf School is ijarah or ujrah. It involves charging the cardholder only fixed fees, which are waived selectively. In return for a prepaid monthly charge, the cardholder is granted a commensurate credit limit. He may incur charges up to that limit. He may also opt, without incurring a penalty and as often as he chooses, to pay less than his outstanding monthly balance. If he pays more than the five percent minimum, the bank will occasionally waive the monthly fee. It is understood, though not stated in the cardholder's agreement with the bank, that the frequency of waivers depends inversely on the average balance. ${ }^{43}$ What the cardholder pays for credit is thus roughly proportional to his average balance. As Visser $(2009,58-70)$ notes, the use of selective waivers mimics the payment structure of conventional credit cards.

Bai al-inah, tawarruq, and ijarah all substitute, then, for interest. Whereas conventional banks charge interest openly and transparently for rolled over credit card balances, Islamic banks do so covertly and deceptively. The differences among the various payment procedures are of degree, rather than kind. The least popular procedure, ijarah, is also the least transparent. Thus, neither the Asian School nor the Gulf School has developed an interest-free credit card. Their products differ from the conventional credit card only cosmetically. Moreover, these variants of the Islamic credit card differ from one another in the thickness of their cosmetics, rather than in some fundamental respect.

Beyond procedures for disguising interest, the two schools differ in the process by which products and practices are judged as Islamic. In both schools, each Islamic bank has a Sharia board whose members collectively decide what is permissible. There is also a Sharia council concerned with matters that apply to the entire Islamic banking sector. The council's authority differs across the two schools. In Malaysia, the Sharia Advisory Council of the Central Bank, whose members have experience in finance, economics, or law, is authorized to regulate any matter relating to Islamic business (SAC, 2015). Its rulings trump the judgments of individual Sharia boards. As a matter of practice, it tries to keep Malaysia's Islamic finance sector from harming growth. For their part, the Gulf countries have an organization to provide guidance and advice on matters common to all Islamic banks. Called the Accounting and Auditing Organization for Islamic Financial Institutions (AAOIFI), its board of trustees consists of financial experts and religious scholars. Like its Malaysian counterpart, it sets

\footnotetext{
${ }^{43}$ For an example of a cardholder agreement based on ujrah, see Saadiq (2014).
} 
sectoral standards. However, it lacks the power to make member countries follow its policies. $^{44}$

Whether associated with the Gulf School or the Asian School, Islamic banks tend to offer multiple credit cards, each for a particular customer profile. Two examples will illustrate that the card menus resemble those of conventional banks.

Abu Dhabi's Al Hilal Bank offers three "fixed cards" whose holders pay a flat monthly fee irrespective of usage up to a set credit limit. Named Classic Fixed Card, Gold Fixed Card, and Platinum Fixed Card, they differ in the magnitude of the credit limit, which is increasing in the fee. Al Hilal also offers eight "covered cards" whose holders pay a predetermined and fixed "murabaha profit rate" for their transactions. Three of them, the Classic, Gold, and Platinum varieties of the Smart Covered Card, have an annual fee. Another three, the Classic, Gold, and Platinum varieties of the Lifetime Smart Covered Card, require a one-time initiation fee. The seventh card is a Football Card for sports fans; it provides discounts at numerous retailers, including Zayed Sports City for sports equipment, MMI Travel for international football matches, and Nike for football kits. Finally, there is a Qibla Card for the devout. Embedded with a compass that points to Mecca, it offers an "easy payment program" and discounts for visits to Mecca and Medina. As an optional feature, the holder of a Qibla Card can have his local retail transactions rounded off to benefit the Red Crescent (Al Hilal, 2014).

Bank Islam Malaysia Berhad (BIMB) offers six Islamic credit cards: World Mastercard-i, Platinum Mastercard-i, Gold Card-i through either Visa or MasterCard, and finally, Classic Card-i through again either Visa or MasterCard. The annual fee differs across the categories, with a discount for holders who already have another BIMB credit card. As a primary card it ranges from RM777 (\$269) for the World Mastercard-i to RM60 (\$21) for a Classic Card-i. ${ }^{45}$ As of November 2014, the "profit charge" follows a three-tier structure, depending on the holder's record in making the minimum monthly payment. Cardholders who have settled promptly for twelve consecutive months pay 13.5 percent per annum; those who have settled promptly for ten of the twelve months in an annual cycle pay 16.0 percent; and others pay 17.5 percent. The pattern indicates that the riskier cardholders pay more for credit.

\footnotetext{
${ }^{44}$ It was established in 1990. According to AAOFI's Sharia standards published in 2010 (Turkish version, 2012), credit cards are prohibited because they provide an interest-bearing revolving credit facility. This decision was reached at its meeting held in May 2000. Despite the emergence of Islamic credit cards in many countries, the AAOIFI has not amended its standards (AAOFI, 2014).

${ }^{45}$ Conversions made at the exchange rate of January 30, 2014.
} 
In contrast to Turkey, where conventional and Islamic banking is separated by law, in Malaysia and the United Arab Emirates banks are allowed to operate in both banking subsectors at once. In particular, some conventional banks have opened Islamic subsidiaries aimed at attracting customers who would otherwise deal with an Islamic bank. At least in principle the financial transactions of the conventional parent banks and those of their Islamic subsidiaries are kept separate, to avoid tainting the latter with interest. ${ }^{46}$ In certain countries, including Malaysia, conventional banks can compete in the Islamic subsector even without establishing a subsidiary, merely by opening an "Islamic window." Running openly interestbearing and ostensibly interest-free transactions through a single bank causes discomfort among observers concerned about Islamic legitimacy. Thus, certain proponents of Islamic banking consider the Islamic credit cards of conventional Malaysian banks as contaminated variants of the credit cards issued by Islamic Malaysian banks. ${ }^{47}$

The "uncontaminated" Islamic credit cards are themselves un-Islamic, according to many leading Islamic thinkers. Numerous fatwas prohibit the use of credit cards, and even the leading standard setter of Islamic banking treats them as un-Islamic. Nevertheless, Islamic banks throughout the world supply them, and tens of millions of Muslims are using them routinely. Islamic suppliers of credit cards have supplied Islamic justifications through their own boards, in order to comfort their employees and customers who care. But Islamic cards provide essentially the same services as their conventional counterparts. More critically, their fees and commissions cover the same ranges as those of conventional credit cards. After more than a decade since the introduction of Islamic credit cards, there is no consensus even among their promoters as to what makes them Islamic. The practices of one country are considered suspect by the scholars of others. Even within any given country, no uniformity exists even among the Islamic cards ofdifferent Islamic banks.

\section{Statistical quest for an "Islamic" identifier of Islamic credit cards}

The observation that Islamic and conventional credit cards hardly differ in terms of payment procedures raises the question of whether anything of economic significance distinguishes them. Irrespective of the shared use of interest as a means of compensation for services provided to cardholders, the cost of using a credit card could vary systematically depending on its type. In principle, the rules of Islam, perhaps informal Islamic rules, or

\footnotetext{
${ }^{46}$ Some customers of these "mixed" banks treat their Islamic and conventional products as perfect substitutes. But pious customers tend to consider the Islamic products as superior.

${ }^{47}$ On the distinctions between Islamic subsidiaries and Islamic windows, see Al-Awsat (2010).
} 
shared cultural elements of Muslim societies, could make a difference. If the interest rates incurred by the users of Islamic credit cards differ systematically from the rates borne by users of conventional cards, it would indicate that the analysis thus far has overlooked something significant. The purpose of this section is to test whether the charges of Islamic credit cards have a family resemblance that is observable in a multi-country comparison involving both card types. One expects to find differences across countries because of differences in factors such as banking regulations, contract enforcement, and demand conditions.

The task is challenging for several reasons. First, in contrast to deposit and borrowing rates, there exist no public data bases conducive to comparing the charges of credit cards within countries, to say nothing of a global data base suitable to our needs here. The relevant information must be collected from bank websites, which vary in comprehensiveness. Second, the fees and rates charged to any given cardholder may differ from those posted on websites; for example, both conventional and Islamic banks offer discounts to large companies and distinguished customers. Third, the charges associated with credit cards differ in form. For certain transactions some cards have fixed charges; others combine a fixed charge with a proportional schedule; for cash withdrawals, for example, those of the National Bank of Abu Dhabi impose a "3 percent fee, or a minimum of AED 99, whichever is greater." Finally, all card suppliers, Islamic or conventional, compete not only through rates but also through various services and privileges. ${ }^{48}$ What a customer obtains in return for a given fee may vary across credit cards.

Under the circumstances, our comparison must involve simplifications. What will emerge is not a full-blown comparison but, rather, one that yields insights that will form, we hope, a basis for more detailed investigations that may become possible in the future. For many credit card users it is the rates that matter first and foremost; side benefits such as shop discounts and airline miles are secondary. On that basis, we consider an individual seeking a credit card for only two reasons: access to cash advances and the right to carry balances forward. The cost of exercising these privileges will depend on both the pertinent interest rates and the applicable fees. Even a small transaction fee or periodic charge may loom large for a modest balance or advance. We thus ask whether, from the perspective of such an individual, the available conventional and Islamic credit cards differ systematically from one another.

\footnotetext{
${ }^{48}$ They include shop discounts, cash machine locations, club memberships, and airline miles. On nonprice competition in the Turkish credit card market, see Akın, Aysan, Kara, Y1ldiran (2011).
} 
The identified international comparison of Islamic and conventional credit card charges requires several preliminary steps. Representative countries must be chosen. Given the foregoing discussion, it is natural to pick Turkey, Malaysia, and the United Arab Emirates. Within each country, representative Islamic and conventional banks must be selected, and, for each type, representative products. Ideally, banks for each country would be selected on the basis of shares of the domestic credit card market. Unfortunately, these shares are available only for Turkey; neither Malaysia nor the UAE makes them public. Under the circumstances, we use bank size, as measured by assets, as a proxy for credit card popularity in Malaysia and the UAE. The underlying assumption is the bank size is correlated with bank share of the credit card market. ${ }^{49}$ As for representative products, we chose credit cards suited to low-end consumers. These have the lowest published charges for revolving balances. ${ }^{50}$ An advantage of focusing on entry-level cards is that it avoids the vagaries of negotiated discounts. Banks extend such discounts to customers expected to have a high transaction volume. With rare exceptions, the charges imposed on low-end consumers match those posted on official websites. ${ }^{51}$ To make the charges comparable across countries, they must be converted to a common currency. ${ }^{52}$ For annual debt rollover charges, one must also adjust for the relevant inflation rates. ${ }^{53}$

\section{Table 7 here}

Table 7 compares cash advance charges for withdrawals up to $\$ 225,{ }^{54}$ across Islamic and conventional cards selected according to the criteria just described. ${ }^{55}$ In each country, a bank, no matter how many distinct credit cards it offers, charges the same fee per cash advance. But irrespective of the card category, there are differences across banks. Again for

\footnotetext{
${ }^{49}$ Consultations with knowledgeable bank officials suggests that the correlation is very high in both countries.

${ }^{50}$ The lowest charges are calculated from the daily effective interest rate (formula in note 56), net of the remaining balance.

${ }^{51}$ The United Arab Emirates has two banks whose credit cards provide rebates on unused portions of credit limits. The rebates depend on the limits themselves, which are customer-specific. Because the information on the determinants of the customer limits not public, we have excluded these banks from our data set.

${ }^{52}$ All charges were converted to US $\$$ at the Bloomberg rates of June 3, 2014: US\$ $1=$ AED $3.6730=$ MYR $3.2295=$ TL 2.1172 .

${ }^{53}$ For 2014, the core annual inflation rate was $8.17 \%$ for Turkey, $2.7 \%$ for Malaysia, and $3.1 \%$ for UAE (Trading Economics, 2015).

${ }^{54}$ Approximate US dollar equivalent of the withdrawal limit of Turkish banks.

55 The first step is to calculate the nominal cost in the local currency for each credit card in the sample. If $A$ is the withdrawal amount, $f$ is the fixed fee per withdrawal, and $p$ is the percentage charge per transaction, then the nominal cash withdrawal fee in the local currency is $F=f+(p A / 100)$. The nominal cost is then corrected for one month's inflation in the local currency to obtain the corresponding real cost. Finally, the real cost is converted to US dollars. We assume that the cardholder makes a single withdrawal and repays it one month later.
} 
both card categories, the charges of the Turkish credit cards tend to lie at the low end of the range, and those of UAE credit cards are generally at the high end. Malaysian credit cards straddle the middle of the range of charges.

\section{Tables 8 and 9 here}

Tables 8 and 9 perform the same exercise with respect to debt rollovers, separately for conventional and Islamic banks, and using the bank base of Table $7 .{ }^{56}$ In each table the rows give the amount to be rolled over and the columns the lowest-cost options for each country. The underlying assumption is that a person intending to carry over a certain amount of debt for one year will search for a credit card that minimizes the corresponding cost. Unlike cash advance charges, those for revolving balances may differ across the credit cards of any given bank. Hence, the entries in any given column may refer to multiple cards of one particular bank. Consider column 1 of Table 9 for the United Arab Emirates. The lowest-cost credit card is the Light Credit Card of the Noor Islamic Bank for a revolving balance up to $\$ 2500$. But for higher balances, the Amal Standard Credit Card of RAKBANK offers the cheapest option. In Table 9 Turkey is represented by only two columns because only two of its Islamic banks allow debt carryovers (see Table 5).

A striking aspect of the two tables is the uniformity for Turkey of the credit rollover cost at each level of debt. The cost is identical for all credit cards, whether conventional or Islamic. This is a consequence of two banking regulations. The first, which was imposed in November 2013, requires every credit-card issuing bank to offer at least one card without an annual fee (Ntvmsnbc 2013, Tümen et al., 2013). The second caps the charges for revolving balances. All banks have opted to set the revolving balance charge at the upper limit. These two features account for the uniformity of the cost of maintaining a given balance. At the lowend no credit card charges an annual fee, and the interest rate is the same across cards. Tables 8 and 9 also reveal that for each card type Malaysian cards usually carry the lowest charge. The charges of Turkish Islamic cards and Emirati conventional cards lie at the top of the range.

\footnotetext{
56 The exercise involves two steps. First, the annual cost of maintaining various revolving balances in the local currency is calculated for each credit card in the sample. If $b$ is the balance, $a$ is the fixed annual fee, $m$ is the monthly fee, and $z$ is the percentage charge per month, the total cost $c$ is

$$
c=a+12 m+\left\{\left(1+\left[\frac{\left(\frac{Z}{100} * 12\right)}{365}\right]^{365}\right) * b-b\right\} .
$$

For some credit cards, one or more of the parameters $a, m$, and $z$ is nil. The second step is to adjust $c$ for inflation and convert it into US dollars.
} 
All together, Tables 7-9 indicate that the rates of Islamic banks show no uniformity across countries. To validate this impression statistically, we present an analysis of variance (ANOVA) that uses a general linear model to detect whether, under suitable controls, statistically significant differences exist between the rates of Islamic and conventional banks. The analysis is conducted for cash withdrawals and debt rollovers separately.

ANOVA is a statistical technique used commonly to test for equality among the means of two or more samples. It compares group variance across samples with variance within them. It is useful especially in dealing with categorical independent variables such as countries and bank types. Another virtue of ANOVA is that it facilitates both the estimation and interpretation of interaction effects.

\section{Table 10 here}

The estimates in Table 10 are based on cash advance charges reported in Table 7 . The estimated model has the following form:

(1) $d_{\mathrm{i}}=\beta_{0}+\beta_{1} T_{\mathrm{i}}+\beta_{2} C_{i}+\beta_{3} C_{i} * T_{i}+u_{i}$,

where $d$ represents the cardholder's cost for each advance amount, $T$ is the bank "type" (conventional or Islamic), $C$ stands for the country (Turkey, Malaysia, or UAE), $i$ indexes the credit cards, and $u$ is an error term.

Although ANOVA is a robust test, the smallness of our samples and the non-normality of the distributions under study make it wise to supplement it with nonparametric tests. The last two columns report results of a Mann-Whitney test as to whether there are systematic cost differences across bank types alone (Islamic vs. conventional) and a Kruskal-Wallis test as to whether systematic differences exist across the three countries. These two nonparametric tests are particularly suitable to small samples.

The intercept term in Table 10 is significant at the $1 \%$ level of statistical significance, as is the variable Country. But the variable Bank type and the cross-variable Bank type*Country are insignificant. The two nonparametric tests support the ANOVA results. The results thus indicate that the differences among the cash advance charges recorded in Table 7 are driven by differences across countries. Put differently, the primary determinant of differences in cash withdrawal charges is that credit cards issuers operate in three different markets. Statistically, it is immaterial whether the issuer is an Islamic or conventional bank.

Table 11 repeats the exercise for the debt rollover charges reported in Tables 8 and 9. By and large the results resemble those of the tests just reported. However, unlike cash 
advance charges, debt rollover charges differ significantly between Islamic and conventional banks and across countries. Our cross variable Bank type*Country is also significant at all debt levels. According to the Mann-Whitney tests, no statistically significant difference is detected up to $\$ 5000$ between two bank types. But the Kruskal- Wallis tests indicate significant differences across countries at all levels.

The results in Table 11 thus reveal some significant differences between the bank types. However, the differences are not systematic. As noted earlier, if they were all following a set of Sharia rules, we would have found systematic differences. As easily seen in Tables 8 and 9, the costs do not differ by bank type in Turkey. In the UAE, by contrast, Islamic banks have relatively lower costs, and in Malaysia the differences depend on the size of the debt. The differences by type are driven mainly by variations within the UAE. When the tests are limited to Turkey and Malaysia, bank type loses statistical significance over the entire range of debt amounts and Table 11 becomes identical to Table 10 .

In sum, neither for cash advance charges nor for debt rollovers does the "Islamic credit card" present characteritics that transcend boundaries. The three countries' Islamic cards resemble their own conventional cards more than one another. Just as avoidance of interest is not a distinguishing feature of Islamic credit cards, so their charges are not distinguishable from those of the conventional credit cards with which they compete. The one possible exception involves debt rollovers in the United Arab Emirates.

This is exactly what one expects in segmented competitive markets. In all three countries people are free to choose among local banks, whether conventional or Islamic; but foreign banks are not an option. Under the circumstances, the Islamic banks of each country compete only with each other and with local conventional banks. They do not take account of foreign Islamic banks.

\section{Markets and Islam}

Islamic economics, which promotes reforms based on Islamic teachings, views markets as tools of economic efficiency. By the same token, it holds that unfettered economic freedoms result in injustices. For markets to generate just results, it claims, players must follow Islamic principles of behavior. Ethically superior and ultimately more satisfying economic outcomes will emerge when financial transactions respect Islamic prohibitions. Developed in the 1940s, this master narrative has now been applied to the credit card. In its conventional form, the credit card is an economic menace, say a subset of Islamic economists; 
to become a a valuable financial tool it must be subjected to Islamic principles. The Islamic credit card thus represents the triumph of Islamic principles over free markets.

The facts point to the opposite conclusion. The conventional credit card originated in financial markets unconstrained by Islam. Islamic banks ignored it as long as few Muslims used it. As credit cards became popular, the architects of Islamic banking initially attributed the unavailability of an Islamic alternative to its incompatibility with Islamic teachings. Eventually, as it the profitability of issuing credit cards became obvious, Islamic banks began to issue credit cards of their own. Given the impracticality apparent impossibility of operating credit cards through an interest-free method, Islamic banks could have refused to issue them. If they opted to issue cards themselves, it is because their customers wanted the conveniences. Refusing to serve customers because of qualms about interest would have resulted in forgone profits and loss of market share to conventional banks.

These observations pertain to financial markets in which Islamic banks compete for market share with conventional banks. In such markets consumer preferences induce Islamic banks to supply services that they consider un-Islamic. The viability of genuinely interest-free finance requires, then, an enforced ban on conventional finance. If the Islamic banks of Turkey, Malaysia, and the United Arab Emirates did not face competition from conventional banks, they could have refrained from supplying credit cards without loss of market share. It is revaling that credit card use is very low in Iran, where the entire banking sector is Islamic (Mojaveri, Hassani, Firouzjaie 2011, 84).

When Islamic banks do issue credit cards, they use methods with Arabic names designed to make them seem Islamic, thus distinguishing their products from those of conventional banks. Regardless of which cosmetic device they use, they charge customers what amounts to interest for rolled over balances and deferred payments. They subordinate what passes as Islamic principles to market pressures in several other ways, too. First of all, whereas the Qur'an $(11: 85,17: 35)$ calls for transparency in transactions, their payment methods serve to obfuscate. Second, whereas the Qur'an calls for moderation in consumption, ${ }^{57}$ Islamic credit cards promote spending impulsively both by making credit available and through advertising that encourages spending. Finally, whereas certain verses of the Qur'an, including 2:280 and 9:60, promote the diminution of economic inequalities, Islamic credit cards compound the handicaps that the poor face in credit markets. They do so by denying cards to people with insufficient collateral or a mediocre credit record, by

\footnotetext{
${ }^{57}$ Some of the key verses are given in note 36.
} 
charging lower commissions per unit of spending to cardholders with high balances, and by targeting wealthy customers.

Turkey's credit card sector features suppliers that depend on religious legitimation as well as ones that do not. At every step of the way, conventional banks have been the first to adopt innovations, and Islamic banks have all been followers. Thus, whereas the charge card became a common service of conventional banks in the early 1990s, the first Islamic charge card was introduced only in 1998. The first bona fide credit card was issued by a conventional bank in 1998; an Islamic credit card followed in 2002. And conventional banks embraced bonus practices in the 1990s, Islamic banks a decade later. The lags observed in Turkey are representative of Islamic finance in general. This is not to say that the global Islamic financial sector acts in concert. In each country where Islamic credit cards have achieved substantial market share, they compete with local conventional cards. Evidently, as a matter of practice the world's Islamic banks pursue market share rather than doctrinal purity.

In Turkey, as elsewhere, bank boards consisting of Sharia experts have ratified policies that have contributed to the expansion of consumer credits among pious people. Even as the school of Islamic economics has continued to produce publications urging consumers to avoid extravagance, and banks to lend to the poor and needy, Islamic banks and their customers have been aping the behaviors of their conventional counterparts. The clients of Islamic banks, who are disproportionately pious, relish access to instant credit and the option of rolling over debt effortlesly. For their part, Islamic banks profit from supplying credit cards. Both sides find comfort in board rulings that characterize their transactions as compatible with Islam. At the very least, they believe that the "Islamic" features of their relationships dampen any harmful consequences. If transfers akin to interest are made, the benefits accrue partly to Islamic charities; and the Islamic identities of these transfers contribute to the broader goal of Islamization.

These developments in Islamic finance are peculiar neither to the credit card nor to the present.The financial practices of Islamic economics, observes Mahmoud El-Gamal (2006), have tended to follow conventional innovations with a delay. When global markets produce an innovation, the community of Sharia experts reflexively label it un-Islamic. The most common objection is that it involves interest. If the practice appears useful, conventional financial firms adopt it, which then puts pressure on their Islamic counterparts to follow suit. Incrementally, Sharia experts produce Islamic rationalizations for practices that they themselves condemned as un-Islamic just a few years earlier. The evolution of Turkey's 
Islamic credit card sector illustrates this religious legitimation process, which El-Gamal dubs "halalization."

It is not in modern times that halalization started to delay the adoption of innovations. Providing examples from the Middle Ages, Jared Rubin (2011) shows that it is among the reasons why the Muslim world, once economically developed by the prevailing global standards, fell behind Western Europe. A key difference between the two regions concerns the dependence of political decision makers on religious authorities for legitimation. The ability of the Church to block innovations diminished faster in the course of the second millenniumthan that of Muslim clerics.

Nothing above implies that charging interest is intrinsically harmful or that the credit card is an instrinsically harmful instrument. Interest is a compensation device that has lubricated credit markets since time immemorial. The credit card economizes on transaction costs and allows the smoothing of consumption; when used responsibly, it enhances economic well-being. Our point is that the "Islamic" character of the Islamic credit card lacks economic substance. It performs the functions of its conventional counterpart but behind a smokescreen that misrepresents, confuses. Massive evidence suggests that efforts to produce a distinctly Islamic credit card have wasted intellectual and administrative resources. 


\section{References}

AAOIFI (Accounting and Auditing Organization for Islamic Financial Institutions), 2012. Faizsiz Bankacılık Standartları, translated by Mehmet Odabaşı and İshak Emin Aktepe. Katılım Bankaları Birliği, Istanbul.

AAOIFI (Accounting and Auditing Organization for Islamic Financial Institutions), 2014. Official website www.aaoifi.org (accessed 31 December 2014).

Abozaid, Abdulazeem, 2008. Credit cards from Shari'a perspective. Presentation to the Islamic Finance Forum, Dubai, 13-17 April, 2008.

Akın, G. Gülsün, Aysan, Ahmet Faruk, Kara, Gazi İshak, Yıldıran, Levent, 2011. Nonprice competition in the Turkish credit card market. Contemporary Economic Policy 29, 593 604.

Aktepe, İshak Emin, 2010. İslam Hukuku Çerçevesinde Finansman ve Bankacılık. Türkiye Katılım Bankaları Birliği Yayınları, Istanbul.

Aktepe, İshak Emin, 2013. Sorularla Katılım Bankacılığı. Türkiye Katılım Bankaları Birliği Yayınları, Istanbul.

Al Arabiya News, 2012. Islamic scholars propose new Shariah board model. September 14. Available at http://english.alarabiya.net/articles/2012/09/14/237943.html.

Albaraka Türk, 2006. Katılım bankacılığı sistemi nedir? Available at www.albarakaturk.com.tr/images/PartDocuments/Katilim_Bankaciligi_Sistemi_Nedir_.p df.

Albaraka Türk, 2012. Albaraka Türk'ün kilometre taşları. In: Faaliyet Raporu 2012. Available at www.albarakaturk.com.tr/rapor/tr/m-1-9.html.

Albaraka, 2013. Albaraka Türk Katılım Bankası A.Ş., 10.06.2013 tarihli organizasyon şeması. At www.albarakaturk.com.tr/images/yatirimci-iliskileri/2013.10.06-OrganizasyonTR.pdf.

Al Hilal, 2014. Credit cards (accessed June 1, 2014).

Asharq Al-Awsat, 2010. Islamic windows or Islamic banks. Asharq Al-Awsat, July 22. Available at www.aawsat.net/2010/07/article55249980/islamic-windows-or-islamicbanks.

Aysan, Ahmet Faruk, 2011). Türkiye kredi kartı piyasası: Sorular, sorunlar. In: Aysan, Ahmet Faruk (Ed.), Türkiye'de Kredi Kartı Piyasası. Türkiye Cumhuriyeti Merkez Bankası, Ankara, pp. 7-30.

Bakhshi, Adil Manzoor, 2006. Developing a Financial Model for Islamic Credit Card for the UK. MSc dissertation, University of Salford.

BDDK, 2011. Bankacılıkta Yapısal Gelişmeler. Bankacılık Düzenleme ve Denetleme Kurumu. Available at www.bddk.org.tr/WebSitesi/turkce/Raporlar/Bankacilikta_Yapisal_Gelismeler/11085byg r_2011.pdf.

BDDK, 2014. Kredi karti bilgileri, Bankacılık Düzenleme ve Denetleme Kurumu. At www.bddk.org.tr/bankabilgileri/kredibilgileri.aspx, accessed January 4, 2014.

BDDK, 2015. İstatistik, Bankacılık Düzenleme ve Denetleme Kurumu. At https://www.bddk.org.tr/websitesi/turkce/Istatistiki_Veriler/Istatistiki_Veriler.aspx (accessed April 5, 2015).

BKM, 2010. 1990-2010, Kayda Değer 20 Yıl. Bankalararas1 Kart Merkezi, Istanbul.

BKM, 2012. Bankalararası Kart Merkezi (BKM) Kart Monitor 2012 Araștırmasının Sonuçlarını Açıkladı. Bankalararası Kart Merkezi (BKM) Basın Bülteni, December 24, 2012.

BKM, 2013. Alışverişlerde Nakit Kullanımı Azalmaya Devam Ediyor. Bankalararası Kart Merkezi (BKM) Basın Bülteni, September 23, 2013. 
BKM, 2015. Dönemsel Bilgiler, Bankalararası Kart Merkezi. At www.bkm.com.tr/donemselbilgiler.bkm (accessed April 5, 2015).

Bank Asya, 2012. Bank Asya Annual Report 2012. Asya Katılım Bankası A.Ş., Istanbul. Available at www.bankasya.com.tr/en/_pdf/2012_Annual_Report.pdf.

Bank Asya, 2013a. Tarihçe. At www.bankasya.com.tr/yatirimci-iliskileri-tarihce.aspx (accessed April 14, 2015).

Bank Asya, 2013b. Asya Card MTV kampanyas1. At www.motorlutasitlarvergisi.com/sorgulama/asya-card-mtv-kampanyasi (accessed December 14, 2013).

Bayındır, Abdulaziz, 2001. Faizsiz sistemde ödemeyi geciktiren borçluya uygulanacak maddi ceza. İstanbul Üniversitesi İlahiyat Fakültesi Dergisi 3, 51-70.

Bayındır, Abdülaziz, 2009. Kredi Kartının Taksitlendirilmesi. At www.suleymaniyevakfi.org/arastirmalar/kredi-kartinin-taksitlendirilmesi.html.

Biter, Kenan, 2014. 1 Şubat'taki yasağın arkasında yatan gerçek! At http://ekonomi.haber7.com/gundem-veriler/haber/1120039-1-subattaki-yasaginarkasinda-yatan-gercek.

Bonusnet, 2015. At www.bonus.com.tr/pages/bonusu-taniyin-bonusnet.aspx.

Bugün, 2011. Albaraka World'e katıld1. July 31. Available at http://ekonomi.bugun.com.tr/albaraka-worlde-katildi-haberi/164442.

Çevik, Serhan and Joshua Charap, 2015. The behavior of conventional and Islamic bank deposit returns in Malaysia and Turkey. International Journal of Economics and Financial Issues 5, 111-124.

Chong, Beng Soon, Liu, Ming-Hua, 2009. Islamic banking: Interest-free or interest-based? Pacific-Basin Finance Journal 17: 125-144.

Din İşleri Yüksek Kurulu Başkanlığı, 2014. Katılım bankaları ile ilgili bazı problemler çalıştayı. At

http://www2.diyanet.gov.tr/dinisleriyuksekkurulu/Sayfalar/HaberDetay.aspx?rid=27\&lst =HaberlerListesi.

Donnelly, Grant, Ksendzova, Masha, Howel, Ryan T., 2013. Sadness, identity, and plastic in over-shopping: The interplay of materialism, poor credit management, and emotional buying motives in predicting compulsive buying. Journal of Economic Psychology 39, 113-125.

Eken, Mehmet Fehmi, 2006. Katılım bankacılığında bir kriz tecrübesi. Akadem $<\dot{I}>k \dot{I} k t i s a t$. Available at www.akademiktisat.net/calisma/banka_finans/katilim_kriz_mfeken.htm.

El-Gamal, Mahmoud A., 2006. Islamic Finance: Law, Economics, and Practice. Cambridge Univ. Press, Cambridge.

Evans, David S., Schamalensee, Richard, 2005. Paying with Plastic: The Digital Revolution in Buying and Borrowing, 2nd ed. MIT Press, Cambridge, MA.

Gross, David B., Souleles, Nicholas S., 2002. Do liquidity constraints and interest rates matter for consumer behavior? Evidence from credit card data." Quarterly Journal of Economics 117, 149-185.

Haber7com, 2006. September 26. Available at http://ekonomi.haber7.com/ekonomi/haber/194402-ihlaszedeler-internet-sitesi-kurdu.

Ilham, Reza Ferdian, Dewi, Miranti Kartika, Rahman, Faried Kurnia, 2008. The practice of Islamic credit cards: A comparative look between Bank Danamon Indonesia's Dirham Card and Bank Islam Malaysia's BI Card. Paper submitted to IAEI International Conference, Surabaya, Indonesia, 1-3 August.

Kahf, Monzer, 2001. Fatawa on credit cards, 8 August 2001. Available at http://monzer.kahf.com/fatawa/2000-2002/FATAWA_CREDIT_CARDS.pdf. 
Kalender, Fatih, 2010. Kredi Kartıyla Taksitli Altın Alınabilir mi? At

www.darusselam.com $/$ index.php?option $=$ com content $\&$ view $=$ article\&id=273:kredikartyla-taksitli-altn-alnabilir-mi\&catid=55: sorular-vecevaplar\&Itemid=57\#comments.

Karaman, Hayrettin, 1998a. Kredi kartı ile alışveriş caiz midir? At www.hayrettinkaraman.net/sc/00110.htm.

Karaman, Hayrettin, 1998b. Finans kurumlarının verdiği kredi kartlarını kullanmak caiz midir? At www.hayrettinkaraman.net/sc/00111.htm.

Karaman, Hayrettin, 2009. Bonus hakkında. At www.hayrettinkaraman.net/sc/00287.htm.

Karahan, Gülfemand, Çakmak, Bahadır, 2011. Türkiye kredi kartı sektöründeki gelişmeler. In: Aysan, Ahmet Faruk (Ed.), Türkiye'de Kredi Kartı Piyasası. Türkiye Cumhuriyeti Merkez Bankası, Ankara, pp. 31-59.

Karamustafa, Osman, Karakaya, Aykut, 2002. 'Banka tercihi, finansal araçların kullanımı ve memnuniyeti: Türkiye' deki özel finans kurumu müşterileri üzerine bir araştırma.

Muhasebe ve Finansman Dergisi 16, 82-96

Kaya, Feridun, 2009. Türkiye'de Kredi Kartı Uygulaması. Türkiye Bankalar Birliği Yayınları, Istanbul.

Konsultasi Muamalat, 2007. Can a credit card ever be halal? August 24. Available at http://konsultasimuamalat.me/2007/08/24/can-a-credit-card-ever-be-halal/.

Kuran, Timur, 2004. Islam and Mammon: The Economic Predicaments of Islamism. Princeton Univ. Press, Princeton, NJ.

Kuran, Timur, ed., 2013. Mahkeme Kayıtları Işığında 17. Yüzyıl İstanbul'unda SosyoEkonomik Yaşam / Social and Economic Life in Seventeenth-Century Istanbul: Glimpses from Court Records, Vols. 9-10. İş Bankası Kültür Yayınları, Istanbul.

Kuveyt Türk, 2011. Declaration of certificates due 2016, October 27. Available at www.londonstockexchange.com/specialist-issuers/islamic/ktsukuk31102016.pdf.

Kuveyt Türk, 2012. Kilometre taşları. In: 2012 Faaliyet Raporu, p. 12. Available at www.kuveytturk.com.tr/Files/KT/pdf/finansal_bilgiler/faaliyet_raporlari/2012FaaliyetRa poru.pdf.

Mojaveri, Hamidreza Salmani, Hassani, Ali, Firouzjaie, Javad Abedi, 2011. Assessing the role of automation in managing of Iranian e-banking and its impact on social benefit. Economia: Seria Management 14, 81-90.

Ntvmsnbc, 2009. Özel finans kurumları sigorta fonu kuruyor. February 23. Available at http://arsiv.ntv.com.tr/news/65676.asp.

Ntvmsnbc, 2013. Aidatsız kredi kartı artık zorunlu. November 7. Available at www.ntvmsnbc.com/id/25477812.

Niringjuerae, Manawee, 2009. Credit Cards from Shairiah Perspective. International Islamic University, Malaysia working paper.

Özsoy, İsmail, Görmez, Birol, Mekik, Seden, 2013. Türkiye'de katılım bankalarının tercih edilme sebepleri: Ampirik bir tetkik. Yönetim ve Ekonomi 20, 187-206.

Öztürk, Ali, 2013. Faizsiz bankacılık ilkeleri ve katılım bankacılığı. Notes for a seminar given by a Kuveyt Türk official on February 3 at the Albaraka conference room. Available at www.tkbb.org.tr/Documents/EgitimVeKonferans/FA\%C4\%B0ZS\%C4\%B0Z\%20BANK ACILIK-\%20KBB-\%20E\%C4\%9E\%C4\%B0T\%C4\%B0M\%20AL\%C4\%B0\%20\%C3\%96ZT\%C3\%9CRK.pdf.

Parker, Mushtak, 2010. Payment delays and defaults. Arab News, April 17. Available at www.arabnews.com/node/349438.

Prelec Drazen, Simester, Duncan, 2001. Always leave home without it: A further investigation of the credit-card effect on willingness to pay. Marketing Letters 12, 5-12. 
Prelec, Drazen, Loewenstein, George, 1998. The red and the black: Mental accounting of savings and debt. Marketing Science 17, 4-28.

Rubin, Jared, 2011. Institutions, the rise of commerce, and the persistence of laws: Interest restrictions in Islam and Christianity. Economic Journal 121, 1310-1339.

Sabah, 2013. Diyanet: Kredi kartıyla altın satılmaz. December 21. Available at www.sabah.com.tr/ekonomi/2013/12/21/diyanet-kredi-kartiyla-altin-satilmaz.

Saadiq, 2014. Saadiq Visa credit cards. At https://www.sc.com/pk/saadiq/saadiq-visa-creditcard.html (accessed June 3, 2014).

Savaşan, Fatih, Saraç, Mehmet, Gürdal, Temel. 2013. Exploring the demand side issues in participation banking in Turkey: Questionnaire survey on current issues and proposed solutions. Afro Eurasian Studies 2, 111-124.

SAC, 2015. Shariah Advisory Council of Bank Negara Malaysia. At http://blink.bnm.gov.my/microsites/financial/pdf/resolutions/04_sac.pdf (accessed April 15, 2015).

Shleifer, Andrei, 2004. Does competition destroy ethical behavior? American Economic Review 94, 414-418.

Schoell, Christopher, 2010. Turkey's credit card industry: Swipe wisely. In Perspectives on Business and Economics in Turkey: Bridging Two Worlds. Martindale Center for the Study of Private Enterprise, Lehigh University, Bethlehem, PA, pp. 33-43.

Solak, Fahri, 2003. Islam ekonomisi ile ilgili Türkçe eserler bibliyografyası. In Şentürk, Recep (Ed.), Ekonomik Kalkınma ve Değerler. UTESAV Kültür Düşünce Yayınları, Istanbul, pp. 363-377.

Son Kale, 2012. Happy Card'la mutlu hacilar! June 27. At www.sonkale.org/happy-card-lamutlu-hacilar-h109731.html.

Sorularla İslamiyet, 2003. Banka kredi kartı ve faiz konusunda bilgi. At www.sorularlaislamiyet.com/m/index.php?oku=6646.

Şahin, Ahmet, 2006. Kredi kartı ile alış veriş caiz midir? Dini Sorularınıza Çözümler. At www.ahmetsahin.org/makaledetay.asp?id=519.

Şahin, Ahmet, 2009. Müşteri ve esnaf açısından, kredi kartı ile alışveriş yapmak caiz mi? Sorularla İslamiyet. At m.sorularlaislamiyet.com/index.php?oku=185163.

TKBB, undated. Katılım Bankacılığı: Nedir? Nasıl Çalışır. Türkiye Katılım Bankaları Birliği, Istanbul. Available at www.tkbb.org.tr/Documents/Brosur/\%C4\%B01k\%20sayfa\%20KATILIM_BANKACILI GI-2.pdf.

TKBB, 2014. Türkiye Katılım Bankaları Birliği: Banka ve sektör bilgileri. At www.tkbb.org.tr/banka-ve-sektor-bilgileri-banka-bilgileri (accessed February 10, 2014).

Trading Economics, 2015. Inflation rates by country. At www.tradingeconomics.com (accessed April 4, 2015).

Tümen, Arzu, Eren, Bekir, Akça, Fatih, Kemeral, İsmail Kerem, Gençay, Mehmet, Akdemirci, Yelda Şahin, 2013. Finansal istikrara yönelik adımlar. Türkiye Cumhuriyeti Merkez Bankası Finansal İstikrar Raporu, November 2013, pp. 69-82. Available at www.tcmb.gov.tr/wps/wcm/connect/aef4007e-a12b-4f49-b7bf-562ecd0cded9/bolumIV17.pdf?MOD=AJPERES\&CACHEID=aef4007e-a12b-4f49-b7bf-562ecd0cded9.

Türkiye, 2000. İhlas Finans'tan bireysel işbirliği. November 14. Available at www.turkiyegazetesi.com.tr/Genel/a86595.aspx.

Türkiye Cumhuriyeti Merkez Bankası, 2013. Bankaların kredi kartı faiz oranları.xls. At www.tcmb.gov.tr (accessed October 20, 2013).

Türkiye Finans, 2014. Declaration of certificates due 2019, April 22. Available at www.centralbank.ie/regulation/securities- 
markets/prospectus/Lists/ProspectusDocuments/Attachments/19957/Project\%20Turkuaz \%202\%20Prospectus\%20-\%20FINAL(12518082_1).pdf.

Vatan, 2004. Diyanet açıkladı: Kredi kartıyla hacca gidilmez. August 31. Available at www.habervitrini.com/magazin/diyanet-acikladi-kredi-kartiyla-hacca-gidilmez-143079/.

Vatan, 2008. Kredi kartiyla ibadet olmaz. December 4. Available at www.gazetevatan.com/kredi-kartiyla-ibadet-olmaz-211975-yasam/.

Visser, Hans, 2009. Islamic Finance Principles and Practice. Edward Elgar, Cheltenham, Glos.

YapıKredi, 2014. Taksit sınırlaması bilgilendirmesi. At www.yapikredipos.com.tr/onemlibilgiler/taksit-sinirlamasi-bilgilendirmesi.aspx, accessed November 5, 2014.

Yılmaz, Osman Nihat, 2010. Faizsiz Bankacılık İlkeleri ve Katılım Bankacılığı. Türkiye Katılım Bankaları Birliği, Istanbul.

Yılmaz, Sedat, Öz, Erkan, 2004. Kuveyt Türk’ten “sıfır faizli” kredi kartı ... September 10. Available at www.habervitrini.com/ekonomi/kuveyt-turkten-sifir-faizli-kredi-karti144354/.

Yeni Şafak, 2001. ÖFK'lara sigorta fonu. February 21. Available at: www.yenisafak.com.tr/arsiv/2001/subat/21/e5.html.

Zaman, 1998. İhlas Finans kredi kartı çıkardı. June 1. Available at http://arsiv.zaman.com.tr//1998/01/06/guncel/ekonomi/all.html. 


\section{Table 1}

Share of participation banks in the Turkish banking sector, end of 2013.

\begin{tabular}{lcccc}
\hline Bank & Assets $(\%)$ & Deposits $(\%)$ & Credit $(\%)$ & Bank branches $(\%)$ \\
\hline Asya & 1.60 & 1.95 & 1.88 & 2.34 \\
Kuveyt Türk & 1.49 & 1.79 & 1.51 & 2.24 \\
Türkiye Finans & 1.45 & 1.59 & 1.66 & 2.09 \\
Albaraka & 0.99 & 1.32 & 1.11 & 1.39 \\
\hline All & 5.54 & 6.66 & 6.16 & 8.05 \\
\hline
\end{tabular}

Source: TKBB (2014).

\section{Table 2}

Sharia Boards of Turkish participation banks, 2013. Names that appear on multiple boards are in bold letters.

\begin{tabular}{|c|c|c|c|c|}
\hline $\begin{array}{c}\text { Islamic } \\
\text { bank }\end{array}$ & Asya & Kuveyt Türk & Türkiye Finans & Albaraka \\
\hline $\begin{array}{l}\text { Sharia } \\
\text { Board } \\
\text { members }\end{array}$ & $\begin{array}{c}\text { Hayrettin Karaman } \\
\text { Hamdi Döndüren } \\
\text { İshak Emin Aktepe } \\
\text { Hamza Aktan }\end{array}$ & $\begin{array}{c}\text { Anwar Shuaib } \\
\text { Abdulsalam } \\
\text { Şefik Karanfil } \\
\text { (d. 2013) } \\
\text { Yusuf Bayındır } \\
\text { Abdullah Durmuş } \\
\text { Ertuğrul Boynukalın }\end{array}$ & $\begin{array}{c}\text { Hayrettin Karaman } \\
\text { Hamdi Döndüren } \\
\text { İshak Emin Aktepe } \\
\text { Ali Güney }\end{array}$ & $\begin{array}{l}\text { Abdul Sattar Abu } \\
\text { Guddah } \\
\text { Ahmed Mohyuiddin } \\
\text { Ahmed } \\
\text { Hayrettin Karaman } \\
\text { Hamdi Döndüren }\end{array}$ \\
\hline
\end{tabular}

Sources: Bank Asya (2012), 67; Kuveyt Türk (2011), 133; Türkiye Finans (2014), 119; Albaraka (2013). 
Table 3

Share of Islamic banks in Turkish credit card market, 2003-13.

\begin{tabular}{lllllllllllll}
\hline \multirow{2}{*}{ Credit cards } & \multicolumn{10}{c}{ Year } \\
\cline { 2 - 12 } & 2003 & 2004 & 2005 & 2006 & 2007 & 2008 & 2009 & 2010 & 2011 & 2012 & 2013 \\
\hline $\begin{array}{l}\text { Number } \\
\text { in } \\
\text { millions }\end{array}$ & $\begin{array}{l}\text { Conventional } \\
\text { banks }\end{array}$ & 19.84 & 26.03 & 29.52 & 31.86 & 36.41 & 41.87 & 42.55 & 46.47 & 48.93 & 51.77 & 55.03 \\
\cline { 2 - 11 } & $\begin{array}{l}\text { Islamic } \\
\text { banks }\end{array}$ & 0.02 & 0.06 & 0.36 & 0.57 & 0.92 & 1.52 & 1.84 & 2.33 & 2.43 & 2.57 & 1.81 \\
\hline & $\begin{array}{l}\text { All } \\
\text { banks }\end{array}$ & 19.86 & 26.09 & 29.88 & 32.43 & 37.33 & 43.39 & 44.39 & 48.80 & 51.36 & 54.34 & 56.84 \\
\hline \multirow{2}{*}{$\%$} & $\begin{array}{l}\text { Conventional } \\
\text { banks }\end{array}$ & 99.9 & 99.8 & 98.8 & 98.2 & 97.5 & 96.5 & 95.9 & 95.2 & 95.3 & 95.3 & 96.8 \\
\hline & $\begin{array}{l}\text { Islamic } \\
\text { banks }\end{array}$ & 0.1 & 0.2 & 1.2 & 1.8 & 2.5 & 3.5 & 4.1 & 4.8 & 4.7 & 4.7 & 3.2 \\
\hline
\end{tabular}

Sources: BDDK (2011), BKM (2015), e-correspondence with the Association of Turkish Participation Banks on February 25, 2013 and May 15, 2014.

\section{Table 4}

Distribution of credit card customers, number of credit cards, and total credit among Turkey's Islamic banks, end of 2013.

\begin{tabular}{lccc}
\hline Islamic bank & Credit card holders (\%) & Credit cards $(\%)$ & Total credit (\%) \\
\hline Asya & 58.1 & 63.1 & 30.6 \\
Kuveyt Türk & 10.5 & 8.7 & 24.6 \\
Türkiye & 24.2 & 19.9 & 27.0 \\
Albaraka & 7.2 & 8.3 & 17.8 \\
\hline All & 100 & 100 & 100 \\
\hline
\end{tabular}

Sources: The information on credit cards draws on e-communication with officials of the Association of Turkish Participation Banks (Türkiye Katılım Bankaları Birliği), February 25, 2013. The remaining figures come from TKBB (2014). 


\section{Table 5}

Key features of Turkey's Islamic credit cards, 2015.

\begin{tabular}{lcccc}
\hline Islamic bank & $\begin{array}{c}\text { Minimum payment } \\
\text { as \% of card bill }\end{array}$ & Installment plan & Bonus plan & Cash advance \\
\hline Asya & $30-40$ & Yes & Asya & No \\
Kuveyt Türk & 100 & Yes & Altın puan & Yes \\
Türkiye & $30-40$ & Yes & Bonus & Yes \\
Albaraka & 100 & No & World & No \\
\hline
\end{tabular}

Sources: Websites of the banks.

\section{Table 6}

Credit card use and general financial indicators for selected countries, 2013.

\begin{tabular}{lcccc}
\hline $\begin{array}{c}\text { Country or country } \\
\text { grouping }\end{array}$ & $\begin{array}{c}\text { Credit cards } \\
\text { per capita }\end{array}$ & $\begin{array}{c}\text { GNP per } \\
\text { capita at } \\
\text { PPP (\$) }\end{array}$ & $\begin{array}{c}\text { Financial } \\
\text { accounts } \\
\text { per capita }\end{array}$ & $\begin{array}{c}\text { Financial } \\
\text { development } \\
\text { index (1-7) }\end{array}$ \\
\hline Asia (except Malaysia) $^{\mathrm{a}}$ & 0.15 & 6,435 & 0.47 & 3.57 \\
Malaysia $_{\text {Gulf Cooperation Council }}{ }^{\mathrm{b}}$ & 0.28 & 16,270 & 0.66 & 4.24 \\
Turkey $_{\text {OECD (except Turkey) }}^{\mathrm{c}}$ & 0.26 & 32,957 & 0.50 & 3.72 \\
\hline
\end{tabular}

Notes: a. China, India, Indonesia, Philippines, Thailand, Singapore, and Vietnam. b. Saudi Arabia and United Arab Emirates. c. Belgium, Canada, Denmark, France, Germany, Israel, Japan, Republic of Korea, Spain, Switzerland, United Kingdom, and United States of America. d. The figure excludes Switzerland.

Sources: Credit cards numbers are computed from data in Euromonitor country reports on credit card transactions, 2012-14 (for the United Kingdom, later data of the United Kingdom Cards Association was used instead) and population data of the World Bank. GNP per capita figures are those of the World Bank. The financial development index is from World Economic Forum. For country groupings, figures are populationweighted averages. Financial accounts per capita refer to sub-populations age 15 or older. 


\section{Table 7}

Cash advance charges for select conventional and Islamic credit card suppliers in Turkey, Malaysia, and the United Arab Emirates, 2014.

\begin{tabular}{|c|c|c|c|c|c|c|c|c|c|c|c|c|c|c|c|c|}
\hline & \multicolumn{10}{|c|}{ Conventional banks } & \multicolumn{6}{|c|}{ Islamic banks } \\
\hline & \multicolumn{4}{|c|}{ Turkey } & \multicolumn{3}{|c|}{ Malaysia } & \multicolumn{3}{|c|}{ UAE } & \multicolumn{2}{|c|}{ Turkey } & \multicolumn{2}{|c|}{ Malaysia } & \multicolumn{2}{|c|}{ UAE } \\
\hline $\begin{array}{c}\text { US } \\
\$\end{array}$ & 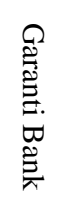 & 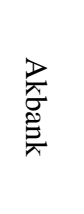 & 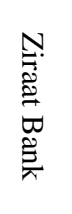 & 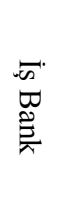 & 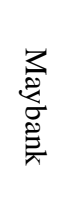 & $\stackrel{\beta}{\frac{\pi}{3}}$ & 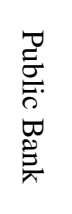 & 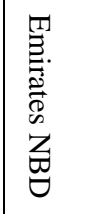 & 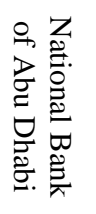 & 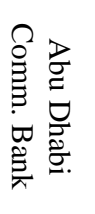 & 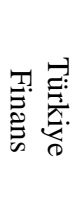 & 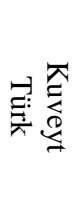 & 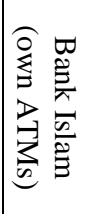 & 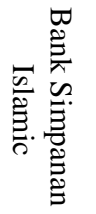 & 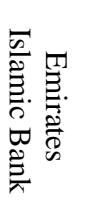 & 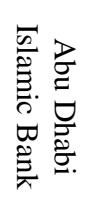 \\
\hline 25 & 3.22 & 4.15 & 1.41 & 2.35 & 3.09 & 4.63 & 6.18 & 26.88 & 27.16 & 13.58 & 0.00 & 0.80 & 3.71 & 15.45 & 24.44 & 20.37 \\
\hline 50 & 4.08 & 5.02 & 1.74 & 2.35 & 3.09 & 4.63 & 6.18 & 26.88 & 27.16 & 13.58 & 0.00 & 1.02 & 3.71 & 15.45 & 24.44 & 20.37 \\
\hline 75 & 4.95 & 5.89 & 2.61 & 2.61 & 3.74 & 4.63 & 6.18 & 26.88 & 27.16 & 13.58 & 0.00 & 1.24 & 3.71 & 15.45 & 24.44 & 20.37 \\
\hline 100 & 5.82 & 6.76 & 3.48 & 3.48 & 4.99 & 4.99 & 6.18 & 26.88 & 27.16 & 13.58 & 0.00 & 1.45 & 3.71 & 15.45 & 24.44 & 20.37 \\
\hline 125 & 6.69 & 7.63 & 4.35 & 4.35 & 6.24 & 6.24 & 6.24 & 26.88 & 27.16 & 13.58 & 0.00 & 1.67 & 3.71 & 15.45 & 24.44 & 20.37 \\
\hline 150 & 7.56 & 8.50 & 5.22 & 5.22 & 7.48 & 7.48 & 7.48 & 26.88 & 27.16 & 13.58 & 0.00 & 1.89 & 3.74 & 15.45 & 24.44 & 20.37 \\
\hline 175 & 8.43 & 9.37 & 6.09 & 6.09 & 8.73 & 8.73 & 8.73 & 26.88 & 27.16 & 13.58 & 0.00 & 2.10 & 4.37 & 15.45 & 24.44 & 20.37 \\
\hline 200 & 9.30 & 10.24 & 6.95 & 6.95 & 9.98 & 9.98 & 9.98 & 26.88 & 27.16 & 13.58 & 0.00 & 2.32 & 4.99 & 15.45 & 24.44 & 20.37 \\
\hline 225 & 10.17 & 11.11 & 7.82 & 7.82 & 11.23 & 11.23 & 11.23 & 26.88 & 27.16 & 13.58 & 0.00 & 2.54 & 5.61 & 15.45 & 24.44 & 20.37 \\
\hline
\end{tabular}

Sources: Websites of the banks.

\section{Table 8}

Inflation-adjusted annual cost of maintaining a revolving balance for select conventional credit card suppliers, Turkey, Malaysia, and United Arab Emirates, 2014.

\begin{tabular}{|c|c|c|c|c|c|c|c|c|c|c|c|c|c|c|c|}
\hline \multirow[b]{2}{*}{ US \$ } & \multicolumn{5}{|c|}{ Turkey } & \multicolumn{5}{|c|}{ Malaysia } & \multicolumn{5}{|c|}{ UAE } \\
\hline & 1 & 2 & 3 & 4 & 5 & 1 & 2 & 3 & 4 & 5 & 1 & 2 & 3 & 4 & 5 \\
\hline 50 & 12.7 & 12.7 & 12.7 & 12.7 & 12.7 & 4.6 & 5.1 & 7.9 & 7.9 & 7.9 & 15.0 & $\begin{array}{l}19.0 \\
\end{array}$ & 19.3 & 20.9 & 20.9 \\
\hline 100 & 25.3 & 25.3 & 25.3 & 25.3 & 25.3 & 9.2 & 10.1 & 15.8 & 15.8 & 15.8 & 30.1 & 37.9 & 38.5 & 41.8 & 41.8 \\
\hline 250 & 63.4 & 63.4 & 63.4 & 63.4 & 63.4 & 22.9 & 25.3 & 39.4 & 39.4 & 39.4 & 75.1 & 94.8 & 96.4 & 104.6 & 104.6 \\
\hline 500 & 126.7 & 126.7 & 126.7 & 126.7 & 126.7 & 45.8 & 50.7 & 65.7 & 65.7 & 65.7 & 150.3 & 189.5 & 192.8 & 209.2 & 209.2 \\
\hline 1000 & 253.5 & 253.5 & 253.5 & 253.5 & 253.5 & 91.7 & 101.3 & 116.4 & 116.4 & 116.4 & 300.5 & 379.0 & 385.5 & 418.4 & 418.4 \\
\hline 2500 & 633.7 & 633.7 & 633.7 & 633.7 & 633.7 & 229.2 & 253.3 & 268.4 & 298.5 & 298.5 & 870.7 & 873.8 & 947.5 & 963.7 & 1046.0 \\
\hline 5000 & 1267.5 & 1267.5 & 1267.5 & 1267.5 & 1267.5 & 458.4 & 551.8 & 551.8 & 551.8 & 657.3 & 1345.3 & 1602.3 & 1895.1 & 1927.5 & 2005.2 \\
\hline 10000 & 2534.9 & 2534.9 & 2534.9 & 2534.9 & 2534.9 & 1163.9 & 1575.4 & 1575.4 & 1575.4 & 1575.4 & 2294.5 & 3059.3 & 3790.1 & 3851.9 & 3855.0 \\
\hline
\end{tabular}

Sources: Websites of the banks. 
Table 9

Inflation-adjusted annual cost of maintaining a revolving balance for select Islamic credit card suppliers, Turkey, Malaysia, and United Arab Emirates, 2014.

\begin{tabular}{|c|c|c|c|c|c|c|c|c|c|c|c|c|}
\hline \multirow[b]{2}{*}{ US \$ } & \multicolumn{2}{|c|}{ Turkey } & \multicolumn{5}{|c|}{ Malaysia } & \multicolumn{5}{|c|}{ UAE } \\
\hline & 1 & 2 & 1 & 2 & 3 & 4 & 5 & 1 & 2 & 3 & 4 & 5 \\
\hline 50 & 12.7 & 12.7 & 4.5 & 5.1 & 7.0 & 7.0 & 7.0 & 10.7 & 10.7 & 10.7 & 10.7 & 15.8 \\
\hline 100 & 25.3 & 25.3 & 9.0 & 10.2 & 14.1 & 14.1 & 14.1 & 21.4 & 21.4 & 21.4 & 21.4 & 31.7 \\
\hline 250 & 63.4 & 63.4 & 22.6 & 25.5 & 35.2 & 35.2 & 35.2 & 53.4 & 53.4 & 53.4 & 53.4 & 79.2 \\
\hline 500 & 126.7 & 126.7 & 45.2 & 50.9 & 70.4 & 70.4 & 70.4 & 106.9 & 106.9 & 106.9 & 106.9 & 158.4 \\
\hline 1000 & 253.5 & 253.5 & 90.4 & 101.9 & 131.3 & 131.3 & 131.3 & 145.5 & 145.5 & 208.3 & 213.7 & 213.7 \\
\hline 2500 & 633.7 & 633.7 & 254.6 & 301.1 & 301.1 & 351.8 & 351.8 & 388.0 & 388.0 & 427.6 & 533.5 & 534.3 \\
\hline 5000 & 1267.5 & 1267.5 & 509.3 & 584.1 & 584.1 & 703.5 & 703.5 & 465.6 & 505.2 & 640.2 & 693.0 & 698.4 \\
\hline 10000 & 2534.9 & 2534.9 & 1018.5 & 1150.1 & 1396.8 & 1407.1 & 1407.1 & 931.1 & 931.1 & 931.1 & 1163.9 & 1385.9 \\
\hline
\end{tabular}

Sources: Websites of the banks.

\section{Table 10}

ANOVA and non-parametric tests for cash advance fees to determine whether statistically significant differences exist across bank types and/or countries.

\begin{tabular}{r|cccc|cc}
\hline & \multicolumn{3}{|c|}{ Summary of ANOVA Results } & \multicolumn{2}{c}{ Nonparametric Tests } \\
\hline US \$ & Intercept & $\begin{array}{c}\text { Bank } \\
\text { type }\end{array}$ & Country & $\begin{array}{c}\text { Bank type } \\
* \text { Country }\end{array}$ & $\begin{array}{c}\text { Mann-Whitney } \\
\text { (Bank type) }\end{array}$ & $\begin{array}{c}\text { Kruksal-Wallis } \\
\text { (Country) }\end{array}$ \\
\hline 25 & Yes*** & No & Yes*** & No & No & Yes*** \\
50 & Yes*** & No & Yes*** & No & No & Yes*** \\
75 & Yes*** & No & Yes*** & No & No & Yes*** \\
100 & Yes*** & No & Yes*** & No & No & Yes*** \\
125 & Yes*** & No & Yes*** & No & No & Yes*** \\
150 & Yes*** & No & Yes*** & No & No & Yes*** \\
175 & Yes*** & No & Yes*** & No & No & Yes*** \\
200 & Yes*** & No & Yes*** & No & No & Yes*** \\
225 & Yes*** & No & Yes*** & No & No & Yes**** \\
\hline
\end{tabular}

Note: $* * * 1 \%$ level of statistical significance. 


\section{Table 11}

ANOVA and non-parametric tests for revolving balance charges to determine whether statistically significant differences exist across bank types and/or countries.

\begin{tabular}{r|cccc|cc}
\hline & \multicolumn{3}{|c|}{ Summary of ANOVA Results } & \multicolumn{2}{c}{ Non-parametric tests } \\
\hline US \$ & Intercept & $\begin{array}{c}\text { Bank } \\
\text { type }\end{array}$ & Country & $\begin{array}{c}\text { Bank type } \\
* \text { Country }\end{array}$ & $\begin{array}{c}\text { Mann- } \\
\text { Whitney } \\
\text { (Bank type) }\end{array}$ & $\begin{array}{c}\text { Kruskal- } \\
\text { Wallis } \\
\text { (Country) }\end{array}$ \\
\hline 50 & Yes*** & Yes*** & Yes*** & Yes*** & No & Yes*** \\
100 & Yes*** & Yes*** & Yes*** & Yes*** & No & Yes*** \\
250 & Yes*** & Yes*** & Yes*** & Yes*** & No & Yes*** \\
500 & Yes*** & Yes*** & Yes*** & Yes*** & No & Yes*** \\
1000 & Yes*** & Yes*** & Yes*** & Yes*** & No & Yes*** \\
2500 & Yes*** & Yes*** & Yes*** & Yes*** & No & Yes*** \\
5000 & Yes*** & Yes*** & Yes*** & Yes*** & Yes** & Yes*** \\
10000 & Yes*** & Yes*** & Yes*** & Yes*** & Yes*** & Yes*** \\
\hline
\end{tabular}

Note: $* * * 1 \%$ level of statistical significance; $* * 5 \%$ level of statistical significance. 


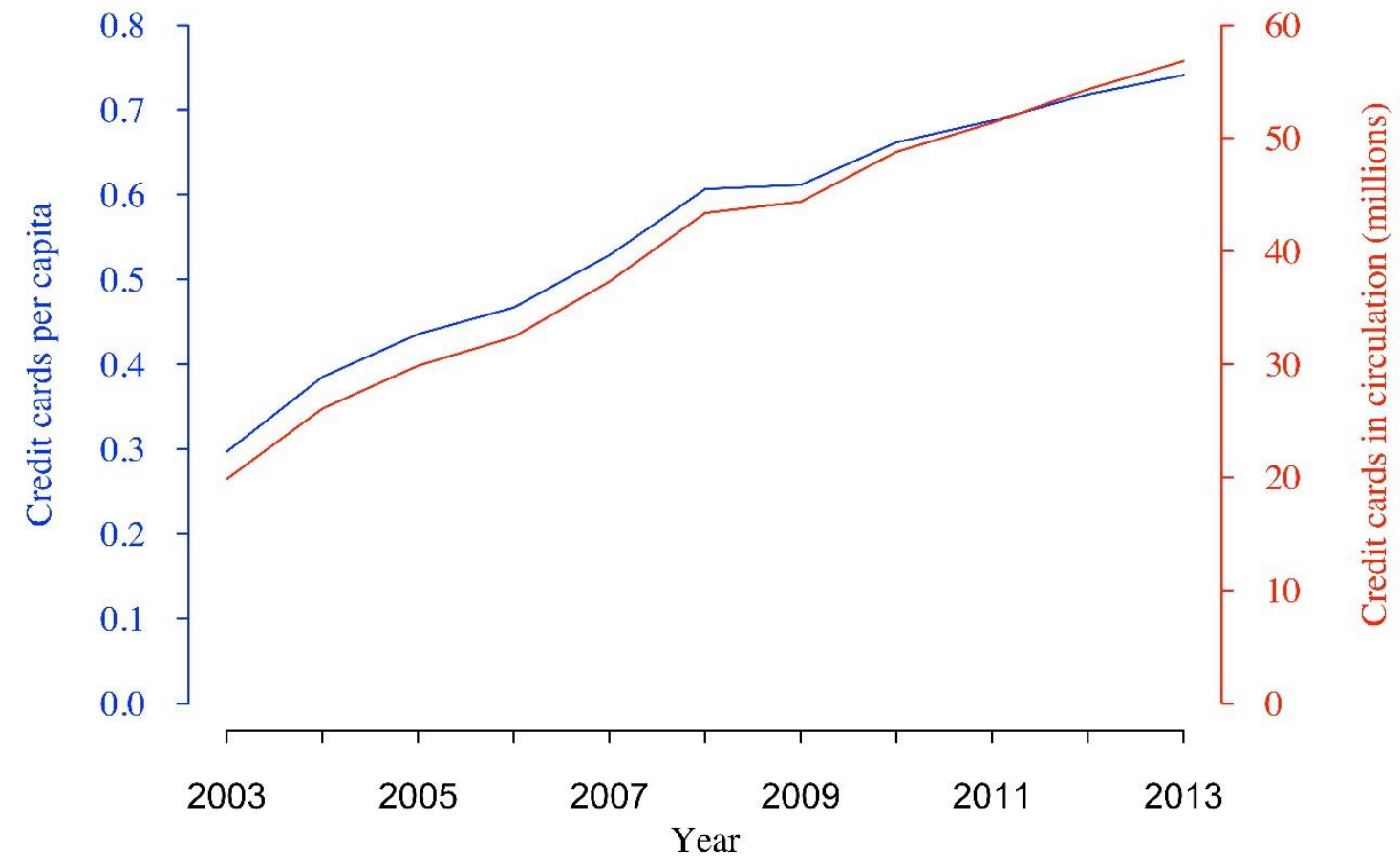

Fig.1. Credit card growth in Turkey, 2003-2013: Total and per capita numbers. Sources: BDDK (2011) and communications with Bankalararası Kart Merkezi (Interbank Card Center). 